\title{
Functional morphology of the buccal complex of Flabellina verrucosa (Gastropoda: Opisthobranchia)
}

\author{
A.L. Mikhlina1, E.V. Vortsepneva², A.B. Tzetlin ${ }^{1}$ \\ ${ }^{I}$ Department of Invertebrate Zoology, Biological Faculty, Moscow State University, 119234 \\ Moscow, Russia. \\ E-mail:azzarika@gmail.com; atzetlin@gmail.com \\ ${ }^{2}$ White Sea Biological Station, Biological Faculty, Moscow State University, 119234 Moscow, \\ Russia. \\ E-mail:vortcepneva@gmail.com
}

ABSTRACT: Buccal complex of Gastropoda is a complex structure consisting of the radula, odontophore and the buccal muscles. The general morphology and function of the buccal complex of Gastropoda was well-studied in several aspects. However, there are only a few integrated studies on both general and fine morphology, and the mechanism of feeding performed on opisthobranchs. Opisthobranchs' feeding mechanisms are very specific and diverse, because opisthobranch molluscs have highly-specified feeding preferences. Unlike the majority of opisthobranchs, Flabellina verrucosa (Gastropoda: Opisthobranchia) has a wide range of feeding objects. The feeding mechanism of this species can be an example of the non-specified feeding mode. General and fine morphology of the buccal complex of $F$. verrucosa is studied in the present work. Based on three-dimensional reconstruction of the buccal complex and data on the fine morphology of muscles, we suggest the mechanism of the functioning of the food-obtaining apparatus. Prey is pulled into the buccal cavity due to blowing negative pressure and triturated using the radula. This feeding mechanism is suggested for Gastropoda for the first time and could be compared only with that in Tochuina tetraquetra and Dendronotus iris (Nudibranchia: Dendronotida), although the morphology of radula in these three species differs considerably.

How to cite this article: Mikhlina A.L., Vortsepneva E.V., Tzetlin A.B. 2015. Functional morphology of the buccal complex of Flabellina verrucosa (Gastropoda: Opisthobranchia) // Invert. Zool. Vol.12. No.2. P.175-196. doi: 10.15298/invertzool.12.2.04

KEY WORDS: radula, buccal muscles, histology, 3D-reconstruction, fine morphology, feeding mechanism.

\section{Функциональная морфология буккального комплекса органов Flabellina verrucosa (Gastropoda: Opisthobranchia)}

\author{
А.Л. Михлина', Е.В. Ворцепнева², А.Б. Цетлин ${ }^{1}$
}

\footnotetext{
${ }^{1}$ Кафедра зоологии беспозвоночных, Биологический факультет, Московскийгосударственный университет имени М.В. Ломоносова, 119234 Москва, Россия.

E-mails:azzarika@gmail.com; atzetlin@gmail.com

${ }^{2}$ Беломорская биологическая станция имени Н.А. Перцова, Московский государственный университет имени М.В. Ломоносова, 119234 Москва, Россия.

E-mail: vortcepneva@gmail.com
} 
PЕЗЮМЕ: Буккальный комплекс органов Gastropoda - это сложная структура, включающая радулу, одонтофор и буккальную мускулатуру. Общая морфология и функционирование буккального комплекса Gastropoda были хорошо изучены в некоторых аспектах. Однако, количество комплексных исследований, посвященных общей и тонкой морфологии, а также механизму функционирования буккального комплекса у заднежаберных моллюсков, крайне мало. Механизмы питания заднежаберных моллюсков очень специфичны и разнообразны, так как пищевые предпочтения представителей этой группы высокоспецифичны. В отличие от большинства заднежаберных моллюсков Flabellina verrucosa (Gastropoda: Opisthobranchia) имеет широкий спектр пищевых объектов. Механизм питания этого вида может быть примером неспецифического типа питания. В данной работе были изучены общая и тонкая морфология буккального комплекса органов $F$. verrucosa. Основываясь на трехмерной реконструкции буккального комплекса органов и данных по тонкому строению буккальной мускулатуры, мы предполагаем механизм функционирования пищедобывательного аппарата. Жертва засасывается в буккальную полость благодаря нагнетанию отрицательного давления и измельчается при помощи радулы. Подобный механизм питания предложен впервые для Gastropoda и может быть сравним только с механизмом питания Tochuina tetraquetra или Dendronotus iris (Nudibranchia: Dendronotida), однако, морфология радулы этих трех видов значительно отличается.

Как цитировать эту статью: Mikhlina A.L., Vortsepneva E.V., Tzetlin A.B. 2015. Functional morphology of the buccal complex of Flabellina verrucosa (Gastropoda: Opisthobranchia)// Invert. Zool. Vol.12. No.2.P.175-196. doi: 10.15298/invertzool.12.2.04

КЛЮЧЕВЫЕ СЛОВА: радула, буккальная мускулатура, гистология, трехмерная реконструкция, тонкая морфология, механизм питания.

\section{Introduction}

General morphology and function of the buccal complex of Gastropoda was well-studied on several species, but the research was often focused on the observation of only one topic, i.e. radular morphology (Eigenbrodt, 1941), movements of the radula and odontophore (Huxley, 1853; Geddes, 1879; Woodward, 1901; Herrick, 1906; Morris, Hickman, 1981; Hickman, Morris, 1985; Smith, 1988; Padilla, 2004), interaction between the radular teeth and the substrate (Hickman, Morris, 1985; Hawkins et al., 1989), or morphology and function of the buccal muscles (Carriker, 1946; Starmühlner, 1952; Fretter, 1965; Graham, 1964, 1973; Nisbet, 1973; Morse, 1984). Complex research of the function of buccal apparatus was performed by Guralnick and Smith (Guralnick, Smith, 1999).
Opisthobranchs usually have highly-specified feeding preferences. It is common that one opisthobranch species feeds on the small group of objects or on a single species, i.e. Tritonia hombergi (Cuvier, 1803) feeds on Alcyonium digitatum L., 1758 (Bulloch, Dorsett, 1979) or Onchidoris bilamellata (L., 1767) feeds only on two species of barnacles: Semibalanus balanoides L., 1767 and Balanus crenatus Bruguière, 1787 (Crampton, 1977). Therefore, opisthobranchs have specific morphological features of the buccal complex, i.e. buccal pump in O. bilamellata (Crampton, 1977), specific radular morphology in Tochuina tetraquetra (Pallas, 1788) (Willows, 1978), acid glands in Pleurobranchaea californica MacFarland, 1966 (Morse, 1984). There are four main feeding modes formerly described for opisthobranchs: lunge-feeding type in T. tetraquetra (Willows, 1978) and Dendronotus iris (J.G. Cooper, 1863) 
(Shaw, 1991); mixed feeding type (piercing and grabbing using radula and suction using buccal pump) in O. bilamellata (Crampton, 1977); raptorial feeding type in $P$. californica (Morse, 1984) and suctorial feeding mode in different sacoglossans (Crampton, 1977). Flabellina verrucosa (M. Sars, 1829) (Nudibranchia: Aeolidida) is not as specified as other opisthobranchs: it feeds on different hydrozoan species, both thecate (Obelia) and athecate (Eudendrium, Ectopleura). Consequently, F. verrucosa has a wider range of feeding objects and it can be called a 'generalist'. Also, feeding process of $F$. verrucosa is an example of the generalist's feeding type and this species can be a model organismfor typical generalist.

The general morphology of the buccal muscles is well-studied for eight opisthobranch species: Armina maculata Rafinesque, 1814 Armina neapolitana (Delle Chiaje, 1824), Armina tigrina Rafinesque, 1814, Armina loveni (Bergh, 1860) (all four of Nudibranchia: Euarminida) (García, García-Gómez, 1990; Kolb, 1998), T. tetraquetra, D. iris (Nudibranchia: Dendronotida) (Willows, 1978; Shaw, 1991), P. californica (Pleurobranchomorpha: Pleurobranchaeidae) (Morse, 1984) and O. bilamellata (Nudibranchia: Doridacea) (Crampton, 1977). The investigation of the fine morphology of the buccal complex was also made for juvenile specimens of Flabellina salmonacea (Couthouy, 1838) (Nudibranchia: Aeolidida) by Hughes (Hughes, 1989). Despite the availability of rather detailed information on the general morphology of the buccal complex, there are only a few studies on both general and fine morphology and the mechanism of feeding in opisthobranch molluscs. Therefore we come to the main purpose of our research: to carry out the integrated investigation of both general and fine morphology and the feeding mechanism of one opisthobranch species, Flabellina verrucosa.

$F$. verrucosa inhabits the tidal and subtidal zones of the White Sea. The basic food resources of this mollusc are various hydroids, especially members of the genera Obelia and Ectopleura (Golikov, 1987). This species occurs near the White Sea biological station during the whole summer season and can be easily kept in an aquarium, so it is a suitable object for longterm experiments and morphological studies.

\section{Material}

Fourty-one specimens of Flabellina verrucosa were collected using SCUBA near the N.A. Pertsov White Sea Biological Station of Moscow State University (66 $33^{\circ} 1824^{\prime \prime} \mathrm{N}, 33^{\circ}$ $08^{\prime} 0874^{\prime \prime} \mathrm{E}$ ), Russia, during the summer seasons of 2012-2015.

\section{Methods}

Twenty specimens of $F$. verrucosa were kept in the sea aquarium at $4{ }^{\circ} \mathrm{C}$ for in vivo observation. Molluscs were starved for 2 days, and then were placed into aquarium with hydroids. The feeding process was photographed, at a speed of one frame per second, using Canon EOS 550D camera with Canon MP-E $65 \mathrm{~mm}$ macro lens.

In order to study the external and internal morphology of the buccal complex, specimens of $F$. verrucosa were relaxed in $0.25 \mathrm{M} \mathrm{MgCl}_{2}$ solution (1:1 with sea water) for 30 minutes, after which their length was measured.

In order to study localisation of the buccal complex in the haemocoel and attachment of the buccal complex to the body wall, 2 specimens of $F$. verrucosa were fixed in $4 \%$ formaldehyde. Dissection of fixed molluscs was performed in fresh water, after which molluscs were stained with methylene-blue and photographed with a Leica MZ6 stereomicroscope.

General morphology of the buccal complex was studied in detail using scanning electron microscopy (SEM). 11 specimens of $F$. verru$\cos a$ were fixed in 2.5\% glutaraldehyde in Millonig phosphatic buffer (Millonig, 1964) (2 min at room temperature, then $2 \mathrm{~h}$ at $4{ }^{\circ} \mathrm{C}$ ). Specimens were rinsed in Millonig phosphatic buffer ( 3 times $\times 10 \mathrm{~min}$ each) and post-fixed with $1 \%$ $\mathrm{OsO}_{4}$ (in the dark, at room temperature, for 1-2 $\mathrm{h}$, depending on the sample size). Next, they were rinsed in Millonig phosphatic buffer (3 times $\times 5$ min each) and dehydrated in graded ethanol series $(30 \%$, followed by $50 \%$, followed by $70 \%$; 2 times $\times 5$ min each). Speci- 
mens were dissected in order to detach the buccal complexes, which were then cut with a razor blade longitudinally and transversally. Then, samples were dehydrated in graded ethanol with acetone as follows: $96 \%$ ethanol for 12 h; $96 \%$ ethanol with acetone (3:1), 2 times $\times 10$ min each; $96 \%$ ethanol with acetone (1:1), 2 times $\times 10$ min each; $96 \%$ ethanol with acetone (1:3), 2 times $\times 10$ min each; acetone $(100 \%)$ for $5 \mathrm{~min}$ and then for $30 \mathrm{~min}$. After dehydration, samples were dried using the critical point method with $\mathrm{CO}_{2}$, mounted on aluminium stubs, and sputter coated with platinum-palladium.

In order to examine the morphology of the radula, the radular apparatus was detached from specimens of $F$. verrucosa in $70 \%$ ethanol, rinsed in $10 \%$ sodium hypochlorite to remove soft tissues, rinsed in distilled water, air-dried, mounted on an aluminium stub, and sputter coated with platinum-palladium.

A detailed observation of the buccal structures was performed using Jeol JSM and FEI Inspect F50 scanning electron microscopes.

In order to study the morphology of the buccal complex with light microscopy, relaxed specimens of $F$. verrucosa were dissected and the buccal complex was detached and fixed as for SEM. Consequently the samples were dehydrated in graded ethanol and acetone and embedded in Epon 812 resin. Five series of semithin sections $(850 \mathrm{~nm})$ were prepared with Dupont MT-5000 and Leica EM UC6 ultramicrotomes using a diamond knife. Sections were stained with methylene-blue and toluidine blue in the $1 \%$ sodium tetraborate.

In order to examine the fine morphology of the buccal musculature using transmission electron microscopy (TEM) 2 specimens of $F$. verrucosa were dissected, fixed, dehydrated and embedded in Epon 812 resin as described for light microscopy. Two series of ultra-thin sections $(80 \mathrm{~nm})$ were prepared with a Leica EM UC6 ultramicrotome using a diamond knife. Sections were stained with uranyl acetate $(1 \%$, $40 \mathrm{~min}, 37^{\circ} \mathrm{C}$ ) and lead citrate (10 min).

Also the whole head of one individual of $F$. verrucosa was prepared for light microscopy and TEM examination.

The examination of the fine morphology was performed using a Jeol JEM transmission electron microscope.
Finally, three-dimensional (3D) reconstructions were made from the series of semi-thin sections for the right half of the buccal complex. Stacks of aligned images were used to reconstruct structures using Bitplane Imaris 7.0.0.

\section{Terminology}

In order to avoid any confusion in terminology, a terminology part has been included, where we explain the usage of terms and their synonyms in this article.

The buccal complex is a complex structure, which takes part in feeding process and includes the radular apparatus, jaws and buccal muscles. This term is equal to the term buccal apparatus (as in Fretter, Graham, 1962).

The buccal cavity is a cavity within the buccal complex. The posterior part of the buccal cavity subdivides into the radular sac and oesophagus. Fretter and Graham (1962) synonymised the buccal cavity with the term pharynx.

The odontophore is a structure of the radular apparatus that includes radular muscles and odontophoral cartilage or radular bolster; sometimes this term is equivalent to the term buccal mass (Fretter, Graham, 1962).

The radular bolster is a supportive structure of the odontophore in opisthobranchs, similar to odontophoral cartilage; this usage of term was suggested by Katsuno and Sasaki (Katsuno, Sasaki, 2008) for the supportive structure of the odontophore constructed by modified myocites and the term was suggested by Voltzow (1994).

\section{Results}

\section{General morphology of the anterior part of the digestive system}

The mouth opening of $F$. verrucosa has a rounded-rhombic shape. It is situated ventrally, and is surrounded by a horseshoe-shaped lip (Fig. 1A). Food passes into the oral tube, which opens into the buccal cavity. The buccal complex of $F$. verrucosa includes paired jaws, strong musculature, and the radula with an odontophore. The oesophagus lies dorsally along the buccal cavity (Fig. 2A, B). The buccal complex has an external lining and is well separated from 

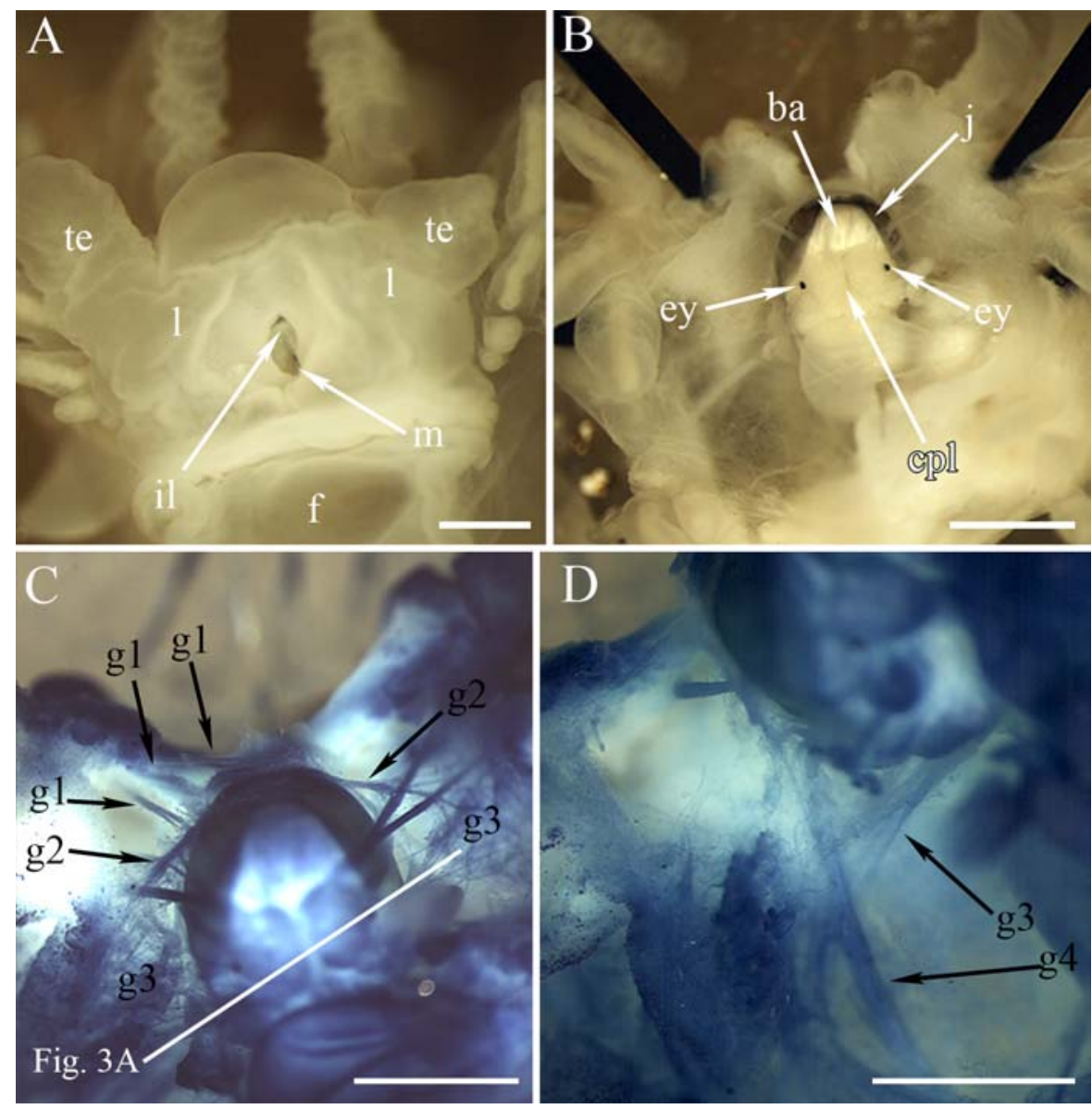

Fig. 1. Morphology of the anterior part of the digestive system of Flabellina verrucosa. A - view from the ventral side; B-D - dissection of anterior part of the digestive system. A - location and shape of mouth opening; B - general view of dissection of anterior part of the digestive system; C - buccal complex's attachment to the body wall; D - fibres attaching the buccal complex to body wall.

Abbreviations: ba - buccal apparatus; $\mathrm{cpl}$ - cerebropleural ganglion; ey - eye; $\mathrm{f}$ - foot; $\mathrm{g} 1$ - first group of connective tissue fibres; g2 - second group of connective tissue fibres; g3 - third group of connective tissue fibres; g4 - fourth group of connective tissue fibres; il - inner lips; $\mathrm{j}$ - jaws; 1 - lip; $\mathrm{m}$ - mouth; te — tentacle.

Scale bar: A $-1 \mathrm{~mm}$; B $-2 \mathrm{~mm}$; C, D $-1.5 \mathrm{~mm}$.

Рис. 1. Морфология переднего отдела пищеварительной системы Flabellina verrucosa.A — вид с вентральной стороны; В-D - вскрытие переднего отдела пищеварительной системы. А - расположение и форма ротового отверстия; В - общий вид вскрытия переднего отдела пищеварительного системы; C - крепление буккального комплекса к стенке тела; D - волокна, прикрепляющие буккальный комплекс к стенке тела.

Обозначения: ba - буккальный аппарат; $\mathrm{cpl}$ — цереброплевральный ганглий; еу — глаз; f — нога; g1 — первая группа соединительнотканных волокон; g2 - вторая группа соединительнотканных волокон; g3 — третья группа соединительнотканных волокон; g4 — четвертая группа соединительнотканных волокон; il — внутренние губы; $\mathrm{j}$ - челюсти; 1 - губа; $\mathrm{m}$ - рот; tе - щупальце.

Масштаб: А -1 мм; B - 2 мм; C, D - 1,5 мм.

other organs. It is roundish-elongate and is noticeable due to the dark colour of the jaws. In specimens of $10-15 \mathrm{~mm}$ in length, the length of the buccal complex varies within a $1.7-2.8 \mathrm{~mm}$ range, and the height and width of the buccal complex are about $70 \%$ of its length. Paired cerebral ganglion with two pigmented eyes lies close to the posterior end of the buccal complex. 

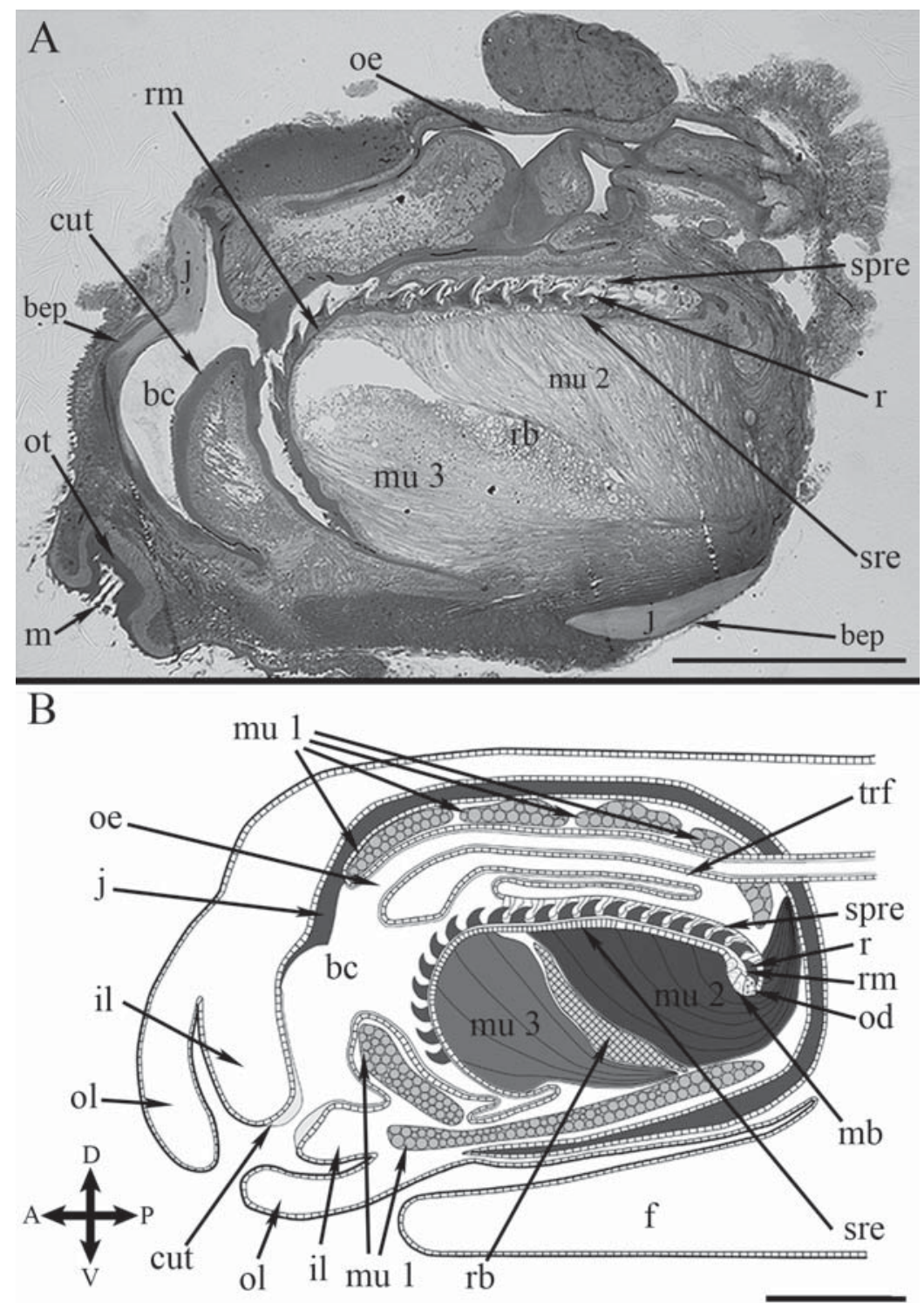

Fig. 2. General morphology of the buccal complex. A - semi-thin sagittal section; B - diagram of the longitudinal section through the buccal complex.

Abbreviations: bc — buccal cavity; bep — buccal epithelium; cut — cuticle; $\mathrm{f}$ - foot; $\mathrm{j}$ - jaw; il — inner lip; $\mathrm{m}$ mouth; $\mathrm{mb}$ - membranoblasts; mu 1 - first group of muscles; mu 2 - second group of muscles; mu 3 - third group of muscles; od — odontoblasts; oe — oesophagus; ol — outer lip; ot — oral tube; $\mathrm{r}$ - radula; rb — radular bolster; $\mathrm{rm}$ radular membrane; spre — supraradular epithelium; sre — subradular epithelium; trf — transversal fold.

Scale bar: A, B $-500 \mu \mathrm{m}$.

Рис. 2. Общая морфология буккального комплекса. А - полутонкий сагиттальный срез; В - схема продольного среза через буккальный комплекс.

Обозначения: bc - буккальная полость; bep - буккальный эпителий; cut - кутикула; $\mathrm{f}$ - нога; $\mathrm{j}$ - челюсть; il - внутренняя губа; $\mathrm{m}$ - poт; $\mathrm{mb}$ - мембранобласты; mu 1 - первая группа мышц; mu 2 - вторая группа мышц; тu 3 - третья группа мышц; od - одонтобласты; oe — пищевод; ol — внешняя губа; ot — ротовая трубка; $\mathrm{r}$ - радула; $\mathrm{rb}$ - радулярный валик; rm - радулярная мембрана; spre - супрарадулярный эпителий; sre субрадулярный эпителий; $\operatorname{trf}$ - поперечная складка.

Масштаб: А, В - 500 мкм 

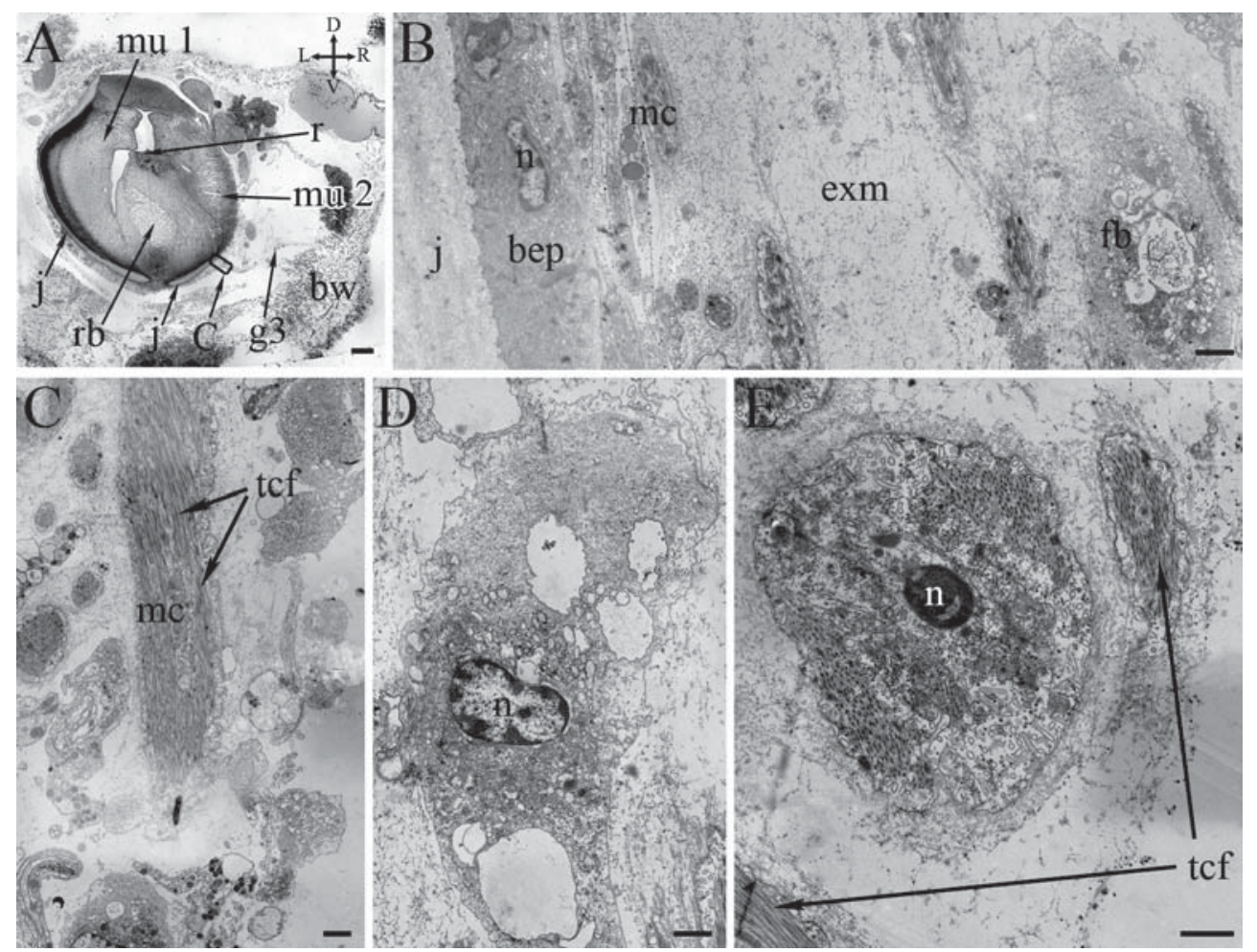

Fig. 3. General and fine morphology of the connective tissue fibres, which attach the buccal complex to the body wall. A - transverse section through the head of the individual; B - originating area of the connective tissue fibre; $\mathrm{C}$ - border area of the connective tissue fibre; $\mathrm{D}$ - fibroblast in the connective tissue fibre; $\mathrm{E}$ - muscle cells in the connective tissue fibre.

Abbreviations: bep — buccal epithelium; bw — body wall; exm — extracellular matrix; fb — fibroblast; g3 — third group of fibres; $\mathrm{j}$ - jaw; $\mathrm{mc}$ - myocyte; mu 1 - first group of muscles; $\mathrm{mu} 2$ - second group of muscles; $\mathrm{n}$ - nucleus; $\mathrm{r}$ - radula; $\mathrm{rb}$ - radular bolster; tcf — thick filaments.

Scale bar: A $-100 \mu \mathrm{m} ; \mathrm{B}, \mathrm{C}-2 \mu \mathrm{m} ; \mathrm{D}, \mathrm{E}-1 \mu \mathrm{m}$.

Рис. 3. Общая и тонкая морфология соединительнотканных волокон, прикрепляющих буккальный комплекс к стенке тела. А - поперечный срез через голову моллюска; В - начальный участок соединительнотканного волокна; C - край соединительнотканного волокна; D - фибробласт в соединительнотканном волокне; Е - мышечная клетка в соединительнотканном волокне.

Обозначения: bep - буккальный эпителий; bw - стенка тела; exm - экстраклеточный матрикс; $\mathrm{fb}$ фибробласт; g3 - третья группа соединительнотканных волокон; $\mathrm{j}$ - челюсть; mс - миоцит; тu 1 - первая группа мышц; тu 2 - вторая группа мышц; $\mathrm{n}$ - ядро; $\mathrm{r}$ - радула; $\mathrm{rb}$ - радулярный валик; tcf — толстые филаменты.

Масштаб: $\mathrm{A}-100$ мкм; $\mathrm{B}, \mathrm{C}-2$ мкм; $\mathrm{D}, \mathrm{E}-1$ мкм.

Nerves branch off from the ganglion to the body wall in different directions (Fig. 1B).

Dissection followed by contrasting using methylene-blue revealed that the buccal apparatus is attached to the body wall by several groups of connective tissue fibres. These fibres can be classified into four groups: 1) the fibres connecting the internal surface of the mouth open- ing with the anterior part of the buccal apparatus (Fig. 1C); 2) the fibres originating from the lateral body wall abreast the mid-length of the buccal complex and attached to the anterior end of the buccal complex (Fig. 1C); 3) numerous thin fibres that link lateral body walls to the ventral side of the buccal complex (Figs 1D; $3 \mathrm{~A})$; and 4) bundles originating behind the buc- 
cal complex, rounding it on both sides laterally, and terminating on the buccal complex anterodorsally (Fig. 1D).

According to the TEM data the connective tissue fibres consist of several types of cells, which are dispersed in the extracellular matrix (Fig. 3B-E). Among them separate muscle cells and large fibroblasts are found (Fig. 3D, E). The fibroblasts have well-developed rough endoplasmic reticulum, numerous vacuoles and ribosomes (Fig. 3D).

\section{Buccal cavity}

The opening of the short oral tube is situated just beyond the mouth. The tube is surrounded by internal lips and continues into the pharynx (buccal cavity) (Figs 2, 4). The oral tube epithelium forms a thick cuticle. The buccal cavity walls form two dorso-lateral folds, where the jaws are located, and a radular diverticulum. The jaw plates are almost entirely covered by the epithelium (Fig. 2). The oral tube and the buccal cavity are lined with a single-layer epithelium which produces a microvillar cuticle. The cuticle in the oral tube is thicker than that in the buccal cavity (Fig. 2).

\section{Radular apparatus}

The radular apparatus is situated in the ventral part of the buccal complex below the oesophagus and includes the odontophore, radula, and radular sheath.

The odontophore is a bearing structure of the radular apparatus which consists of two groups of muscles and a radular bolster, which contains highly vacuolated cells. In sagittal sections, the radular bolster appears as an elongated, irregularly spindle-shaped structure 690$700 \mu \mathrm{m}$ long, $140-150 \mu \mathrm{m}$ thick at the bottom part rapidly narrowing upwards. The radular bolster lies between the odontophoral musculature and the muscles linking the odontophore to the jaw musculature (Figs 4, 7).

The radula of $F$. verrucosa is underlaid by the radular membrane along its entire length. It is U-shaped with the ventral ramus about half as long as the dorsal ramus. The radular formula is
15-21 $\times 1.1 .1$; each transversal row consists of one rachidian tooth flanked by two lateral teeth. Large specimens (more than $17 \mathrm{~mm}$ long) have rachidian teeth that are 60-70 $\mu \mathrm{m}$ long. Each rachidian tooth is curved and triangular with a horseshoe-shaped base, surrounded by the radular membrane. It bears a large central cusp with 5-8 denticles on each side. Lateral teeth are knife-shaped, bearing 5-10 denticles on the inner edge (Fig. 5). In total, the radula is formed by 15 to 21 transversal rows of teeth depending on the size of the individuals.

\section{Jaws}

The jaws of $F$. verrucosa are paired browncoloured structures, which lie in the anterior part of the buccal complex and cover about two-thirds of the buccal complex's length (Fig. 1B). The jaws lie in the folds of the buccal epithelium, but the internal surface of the anterior part of the jaw plates is not covered by the epithelium and is turned inward to the buccal cavity (Figs 2; 4; $11 \mathrm{E})$. Long masticatory processes, bearing small denticles on their edges and surrounding the oral tube, are also not covered by epithelium. The jaw plates are linked to one another by a circular elastic ligament overlying the anterior part of the buccal complex. The anterior edges of the jaws encircle the oral tube (Figs 4A; 6A, B, D).

The jaw is bow-shaped in the sagittal section, and the thickness of different parts of the jaw varies. In front of the oral tube, where the two jaw plates are connected to each other, their thickness is $72.5 \mu \mathrm{m}$ (for specimen $13 \mathrm{~mm}$ long). Below this part, jaw thickness decreases to $43.5 \mu \mathrm{m}$, then increases towards the ventral side reaching $94 \mu \mathrm{m}$ at the midpoint, after which it dramatically diminishes to $25 \mu \mathrm{m}$. The thickness of the jaw plate gradually increases to $70-71 \mu \mathrm{m}$ in the posterior third of the jaw, after which it gradually declines. The edge of the jaw on the dorsal side is $40-45 \mu \mathrm{m}$ thick on average, expanding to 65 $\mu \mathrm{m}$ for the posterior third (Fig. 2A).

SEM photos of a transverse section of the jaw with a section thickness of $67-70 \mu$ m clearly shows that it consists of three layers: two external smooth layers with a thickness of 10-11 $\mu \mathrm{m}$ and a thick, crumbly, alveolate layer between them with a thickness of 49-50 $\mu \mathrm{m}$ (Fig. 6C). 

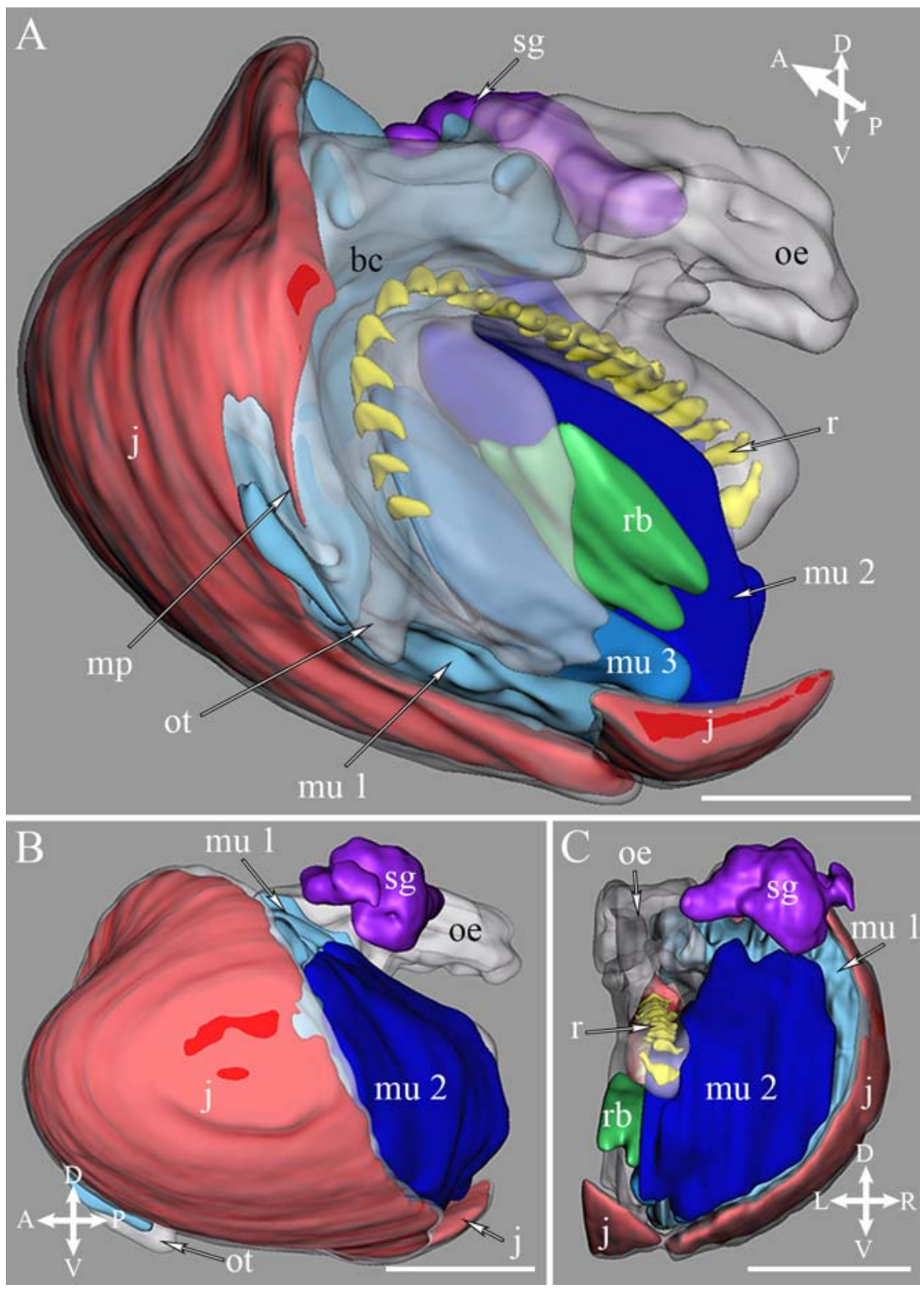

Fig. 4. Three-dimensional reconstruction of a right half of the buccal complex of Flabellina verrucosa. A antero-sagittal view; $\mathrm{B}$ - lateral view of the left half; $\mathrm{C}$ - posterior view.

Abbreviations: bc - buccal cavity; $\mathrm{j}$ - jaw; $\mathrm{mp}$ - masticatory process; mu 1 - first group of muscles (jaw opener muscles); mu 2 - second group of muscles (radular retractors); mu 3 - third group of muscles (odontophoral protractor); oe - oesophagus; $\mathrm{r}$ - radula; $\mathrm{rb}$ - radular bolster; $\mathrm{sg}$ — salivary gland.

Scale bar: A-C $-500 \mu \mathrm{m}$.

Рис. 4. Трехмерная реконструкция правой половины буккального комплекса Flabellina verrucosa. A антеро-сагиттальный вид; В - вид левой половины сбоку; С — вид сзади.

Обозначения: $\mathrm{bc}$ - буккальная полость; $\mathrm{j}$ - челюсть; $\mathrm{mp}$ - жевательный отросток; $\mathrm{mu} 1$ - первая группа мышц (раскрыватели челюстей); тu 2 - вторая группа мышц (радулярные ретракторы); mu 3 - третья группа мышц (протрактор одонтофора); ое - пищевод; $\mathrm{r}$ - радула; $\mathrm{rb}$ - радулярный валик; $\mathrm{sg}$ - слюнная железа. Масштаб: A-C -500 мкм. 

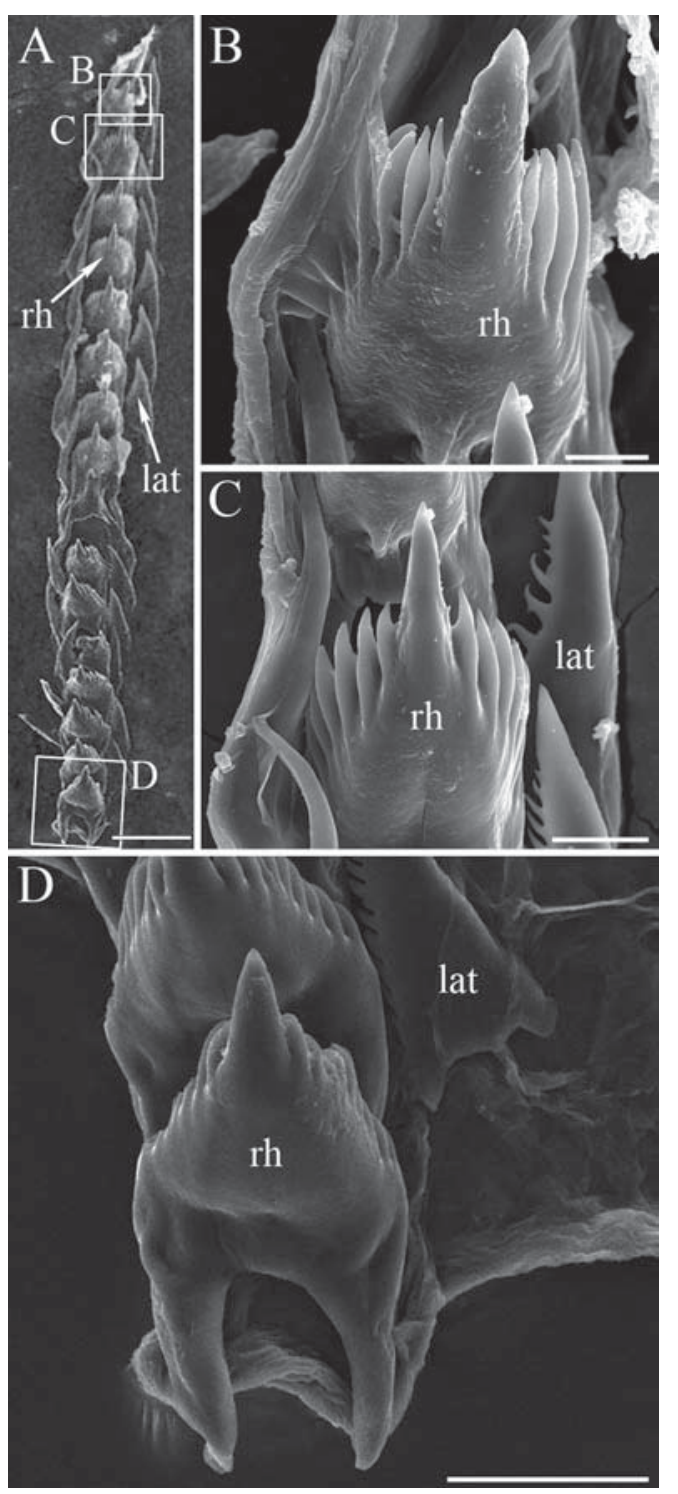

Fig. 5. Radular morphology, SEM. A - general view of the radula; $\mathrm{B}$ - distal part of the radula; $\mathrm{C}$ middle part of the radula; $\mathrm{D}$ - proximal part of the radula.

Abbreviations: lat - lateral tooth; rh - rachidian tooth. Scale bar: A $-100 \mu \mathrm{m}$; B, C $-10 \mu \mathrm{m}$; D $-20 \mu \mathrm{m}$.

Рис. 5. Морфология радулы, СЭМ. А - общий вид радулы; В - дистальная часть радулы; С средняя часть радулы; D — проксимальная часть радулы.

Обозначения: lat — латеральный зуб; rh — рахидальный зуб.

Масштаб: A -100 мкм; $\mathrm{B}, \mathrm{C}-10$ мкм; D -20 мкм.

\section{Musculature of the buccal complex}

According to the three-dimensional reconstruction, there are three main groups of muscles within the buccal complex: 1) the musculature originating from the jaw plates and inserting the wall of the buccal cavity, 2) the musculature originating from the posterior part of the jaw plates and inserting the odontophore and 3) the odontophoral musculature (Figs 4, 7-11).

The first group of muscles - the musculature originating from the jaw plates and inserting the wall of the buccal cavity - occupies the majority of the buccal complex and is composed of twelve muscle bundles (six bundles on the right and left) that are adjacent to one another (Figs 4, 7, 9). These muscles are located in the fold of the buccal epithelium and link the central part of the jaw plates with the wall of the buccal cavity. Two muscle bundles are linked to the oral tube; two muscle bundles line the ventral side of the buccal complex and other bundles lie above the oesophagus (Figs 7-9). According to the TEM data they are obliquely striated (Figs 10B; 11B, D).

The second group of muscles - the musculature originating from the posterior part of the jaw plates and inserting the odontophore - is attached to the posterior part of jaw plates and one of the muscle bundles of the first group of muscles, then it enters the upper part of odontophore and attaches to the radular membrane (Figs $7 ; 8 ; 10 \mathrm{~A}$ ). These muscles are also obliquely striated like the musculature originating from the jaw plates and inserting the wall of the buccal cavity (Fig. 10C, D).

The odontophoral musculature is a single muscle bundle that lies under the radular bolster and consists of longitudinal fibres, which are attached to the subradular membrane and spread caudally to the ventral side of the odontophore, where they are attached to the ventral muscle bundle of the first group of muscles (Figs 7;8). Similar to two groups of muscles described above, this musculature is also obliquely striated (Fig. 11C). 

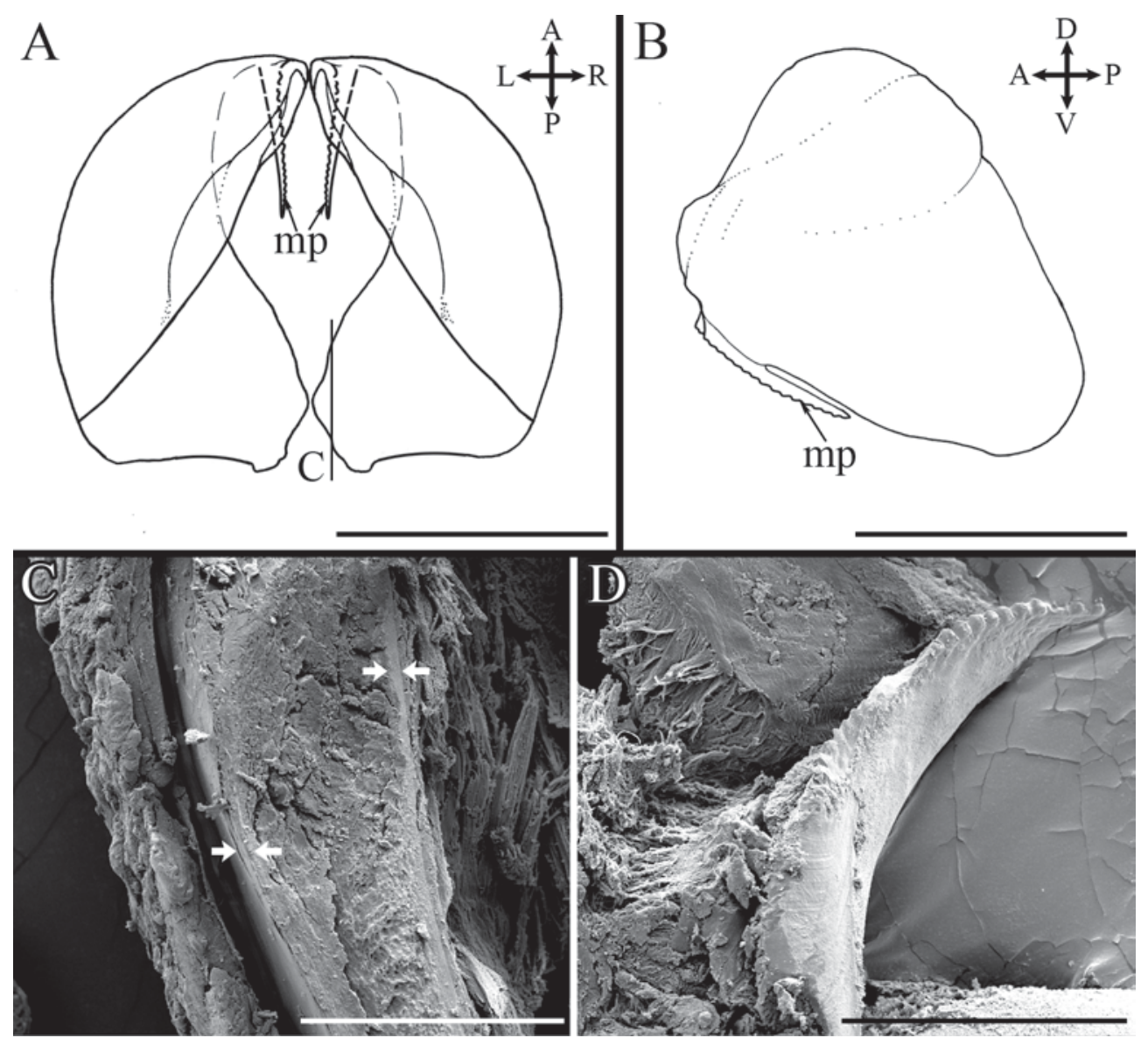

Fig. 6. The jaw morphology. A — diagram of the jaws, dorsal view; B - diagram of the jaws, right lateral view; $\mathrm{C}$ - transversal section through the jaw plate, arrows indicate the borders of different layers, SEM; $\mathrm{D}$ - masticatory process, SEM.

Abbreviations: $\mathrm{mp}$ - masticatory process.

Scale bar: A, B $-1 \mathrm{~mm}$;, $\mathrm{D}-100 \mu \mathrm{m}$.

Рис. 6. Морфология челюстей. А - схема строения челюстей, вид сверху; В - схема строения челюстей, вид справа сбоку; $\mathrm{C}$ - поперечный срез через челюстную пластинку, стрелки показывают границы слоев, СЭМ; D - жевательный отросток, СЭМ.

Обозначения: $\mathrm{mp}$ - жевательный отросток.

Масштаб: А, В - 1 мм; C, D - 100 мкм.

\section{Discussion}

\section{Function of the buccal complex}

Although the buccal apparatus of $F$. verrucosa is similar to those in other gastropods in general structural plan (it consists of jaws, muscles and the radula with the odontophore), it has several distinctive features. The first of these features is the fixation of the buccal complex in the mollusc's body. In all gastropod molluscs studied to date a set of well-developed muscles attaches the buccal complex to the body wall or shell, and manages the buccal complex as a single unit. This musculature is represented by strong muscle bundles (Geddes, 1879; Carriker, 1946; Starmühlner, 1952; Fretter, Graham, 1962; Graham, 1964, 1973; Fretter, 1965; Nisbet, 

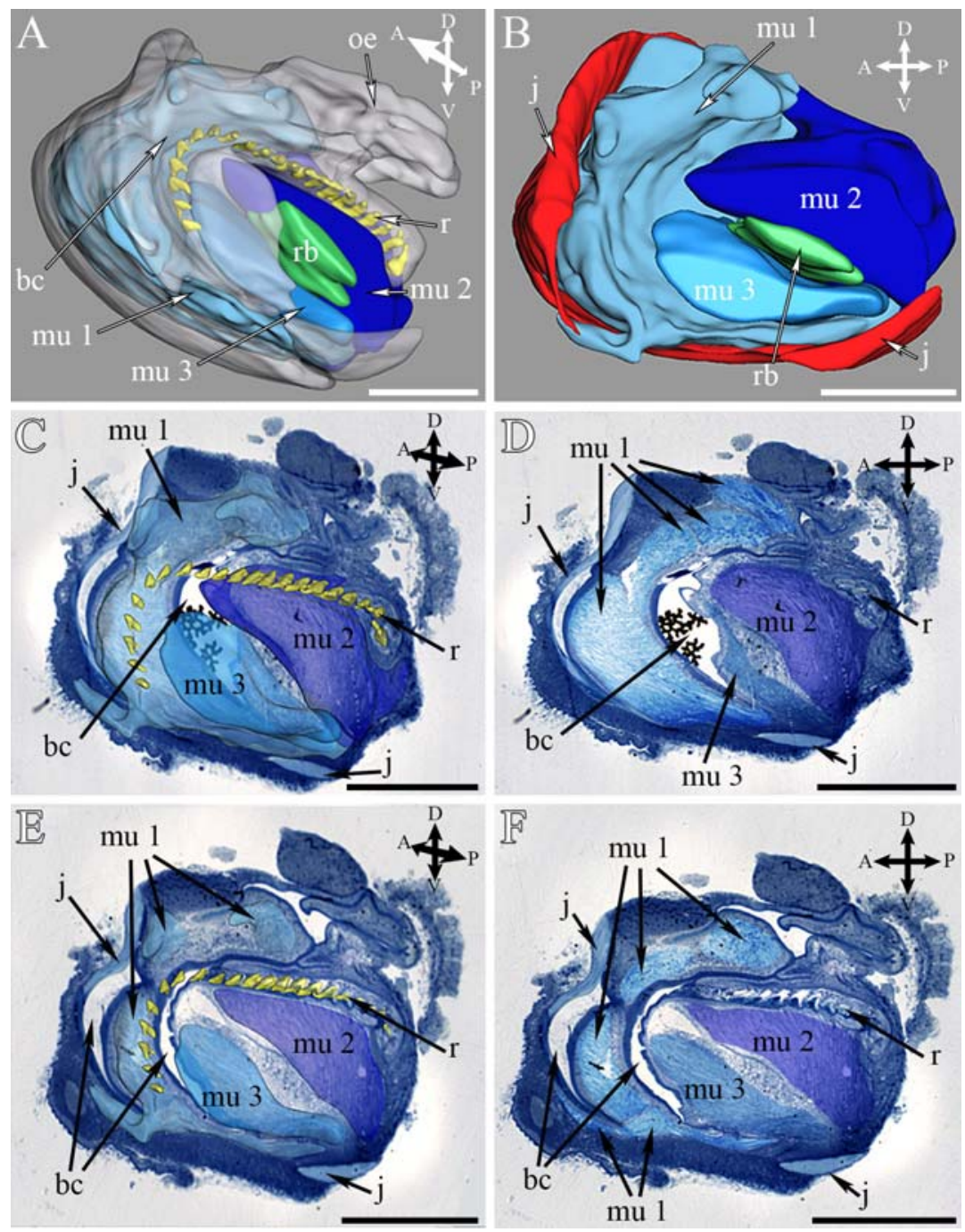

Fig. 7. Buccal complex musculature. A - antero-sagittal view, jaw is not shown; B - median view; C three-dimensional reconstruction combined with the sagittal section through the lateral part of the buccal complex, jaw is not shown; D - sagittal section through the lateral part of the buccal complex; E - threedimensional reconstruction combined with the sagittal section near the middle of the buccal complex, jaw is not shown; F - sagittal section near the middle of the buccal complex.

Abbreviations: bc - buccal cavity; $\mathrm{j}$ - jaw; mu 1 - first group of muscles (jaw opener muscles); mu 2 - second group of muscles (radular retractors); mu 3 - third group of muscles (odontophoral protractor); oe - oesophagus; $r$ - radula; $\mathrm{rb}$ - radular bolster.

Scale bar: A-F $-500 \mu \mathrm{m}$.

Рис. 7. Мускулатура буккального комплекса. А — антеро-сагиттальный вид, челюсть не показана; В медианный вид; C - трехмерная реконструкция в сочетании с сагиттальным срезом боковой части буккального комплекса, челюсть не показана; D — сагиттальный срез через боковую часть буккального комплекса; E- трехмерная реконструкция в сочетании с сагиттальным срезом у середины буккального комплекса, челюсть не показана; F - сагиттальный срез у середины буккального комплекса.

Обозначения: $b c$ - буккальная полость; $\mathrm{j}$ - челюсть; mu 1 - первая группа мышц (раскрыватели челюстей); mu 2 - вторая группа мышц (радулярные ретракторы); тu 3 - третья группа мышц (протрактор одонтофора); oe - пищевод; $\mathrm{r}$ - радула; $\mathrm{rb}$ - радулярный валик.

Масштаб: A-F - 500 мкм. 


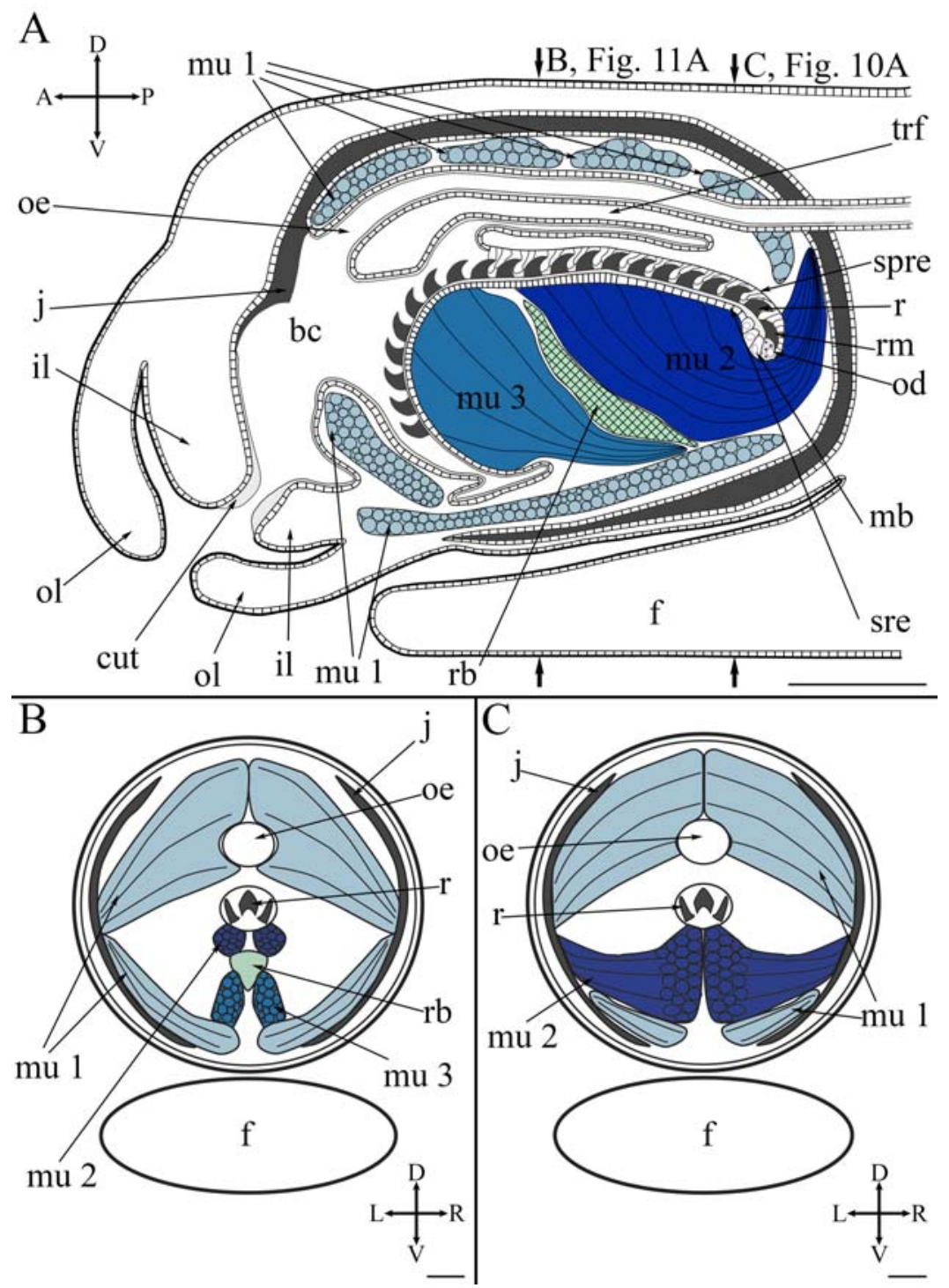

Fig. 8. Diagrams of the buccal complex. A - diagram of the sagittal section of the individual's head; B diagram of the transverse section through the middle of the buccal complex; $\mathrm{C}$ - diagram of the transverse section through the posterior part of the buccal complex.

Abbreviations: bc — buccal cavity; cut — cuticle; $\mathrm{f}$ - foot; $\mathrm{j}$ - jaw; il — inner lip; mb - membranoblasts; mu 1 jaw opener muscles; mu 2 - radular retractors; mu 3 - odontophoral protractor; oe - oesophagus; $r$ - radula; $r b$ radular bolster; rm - radular membrane; spre - supraradular epithelium; sre — subradular epithelium; trf — transversal fold.

Scale bar: A $-500 \mu \mathrm{m} ; \mathrm{B}, \mathrm{C}-100 \mu \mathrm{m}$.

Рис. 8. Схемы строения буккального комплекса. А - схема сагиттального среза через голову моллюска; В - схема поперечного среза через середину буккального комплекса; C - схема поперечного среза через заднюю часть буккального комплекса.

Обозначения: bc - буккальная полость; cut — кутикула; $\mathrm{f}$ - нога; $\mathrm{j}$ — челюсть; il — внутренняя губа; $\mathrm{mb}$ мембранобласты; тu 1 - раскрыватели челюстей; тu 2 - радулярные ретракторы; тu 3 - протрактор одонтофора; ое - пищевод; $\mathrm{r}$ - радула; $\mathrm{rb}$ - радулярный валик; rm - радулярная мембрана; spre супрарадулярный эпителий; sre - субрадулярный эпителий; $\operatorname{trf}$ - поперечная складка.

Масштаб: А -500 мкм; В, C - 100 мкм. 


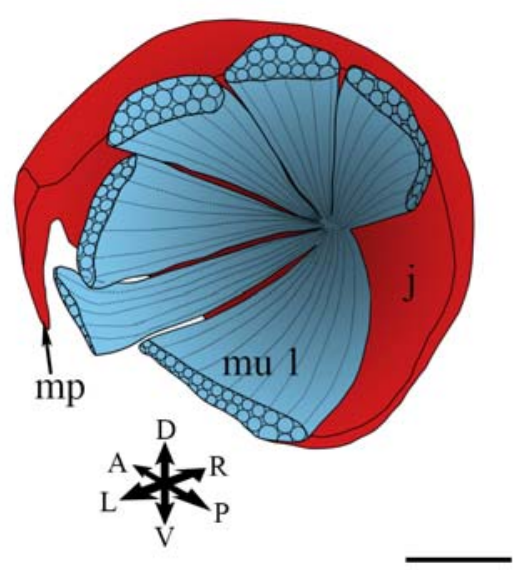

Fig. 9. Diagram of the jaw opener muscles (first group of muscles).

Abbreviations: $\mathrm{j}$ - jaw; $\mathrm{mp}$ - masticatory process; mu 1 - jaw opener muscles.

Scale bar: $500 \mu \mathrm{m}$.

Рис. 9. Схема строения раскрывателей челюстей (первой группы мышц).

Обозначения: $\mathrm{j}$ - челюсть; mp — жевательный отросток; ти 1 - раскрыватели челюстей.

Масштаб: 500 мкм.

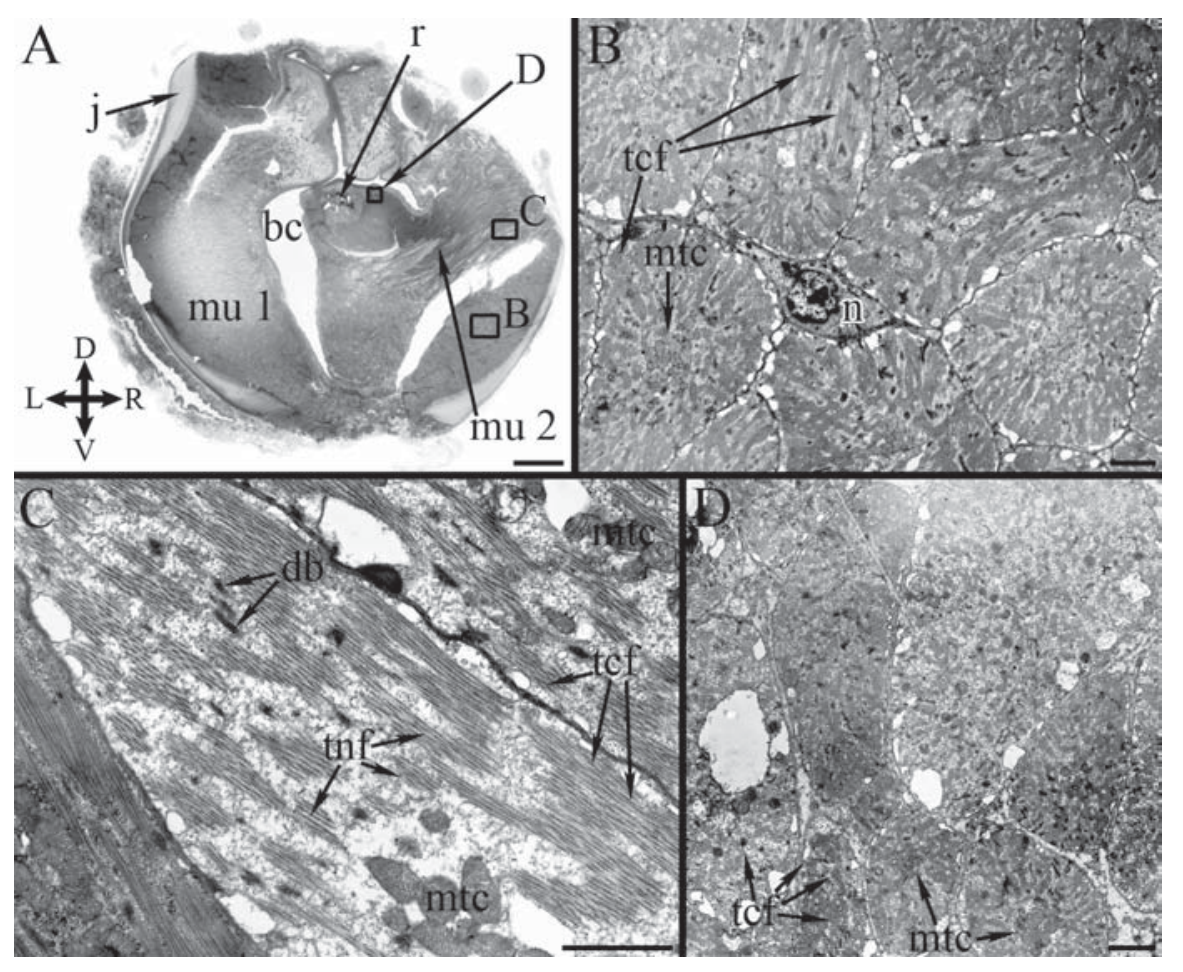

Fig. 10. General and fine structure of the buccal muscles. A - transverse section through the posterior area of the buccal complex; B - ultrastructure of the jaw opener muscles; C - ultrastructure of the radular retractor; D - ultrastructure of the radular retractor near the radular sheath.

Abbreviations: bc — buccal cavity; $\mathrm{db}$ - dense bodies; $\mathrm{j}$ - jaw; mtc - mitochondria; mu 1 - jaw opener muscles; mu 2 - radular retractors; $\mathrm{n}$ - nucleus; $\mathrm{r}$ - radula; tcf — thick filaments; thf — thin filaments.

Scale bar: A $-100 \mu \mathrm{m}$; B-D $-2 \mu \mathrm{m}$.

Рис. 10. Общая и тонкая морфология буккальных мышц. А - поперечный срех через заднюю часть буккального комплекса; В - тонкое строение мышц-раскрывателей челюстей; С - тонкое строение радулярного ретрактора; D — тонкое строение радулярного ретрактора около радулярного влагалища. Обозначения: bc - буккальная полость; $\mathrm{db}$ - плотные тельца; $\mathrm{j}$ - челюсть; $\mathrm{mtc}$ - митохондрии; mu1 раскрыватели челюстей; mu 2 - радулярные ретракторы; n - ядро; $\mathrm{r}$ - радула; tcf — толстые филаменты; $\mathrm{tnf}$ тонкие филаменты.

Масштаб: A - 100 мкм; B-D - 2 мкм. 

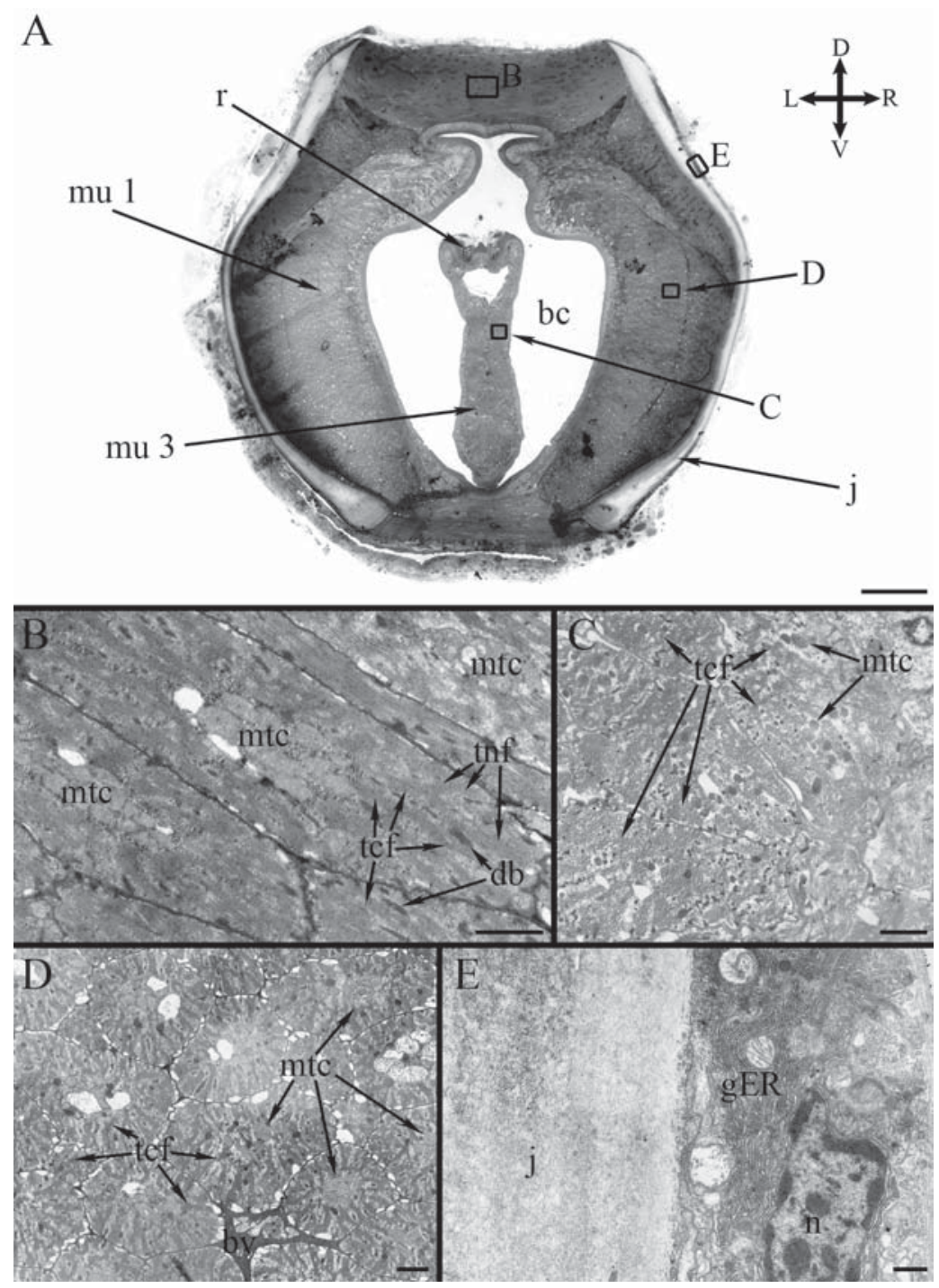

Fig. 11. General and fine morphology of the buccal complex. A - transverse section through the middle area of the buccal complex; B - ultrastructure of the jaw opener muscles on the dorsal side of the buccal complex; $\mathrm{C}$ - ultrastructure of the odontophoral protractor; $\mathrm{D}$ - ultrastructure of the jaw opener muscles in the lateral part of the buccal complex; E - ultrastructure of the epithelium covering the jaw.

Abbreviations: bc — buccal cavity; bv — blood vessel; db — dense bodies; gER — granular ER; $\mathrm{j}$ - jaw; mtc mitochondria; mu 1 - jaw opener muscles; mu 3 - odontophoral protractor; $\mathrm{n}$ - nucleus; $\mathrm{r}$ - radula; tcf - thick filaments; $\operatorname{tnf}$ - thin filaments.

Scale bar: A $-100 \mu \mathrm{m}$; B-D $-2 \mu \mathrm{m}$; E $-0.5 \mu \mathrm{m}$.

Рис. 11. Общая и тонкая морфология буккального комплекса. А - поперечный срез через центральную часть буккального комплекса; В - тонкое строение мышц-раскрывателей челюстей на дорсальной стороне буккального комплекса; C - тонкое строение протрактора одонтофора; D - тонкое строение мышц-раскрывателей челюстей в латеральной части буккального комплекса; E — тонкое строение эпителия, покрывающего челюсть.

Обозначения: bc - буккальная полость; bv — кровеносный сосуд; $\mathrm{db}$ — плотные тельца; gER — гранулярный ЭПР; j - челюсть; mtc - митохондрии; mu 1 - раскрыватели челюстей; mu 3 - протрактор одонтофора; $\mathrm{n}$ ядро; r - радула; tcf - толстые филаменты; tnf — тонкие филаменты.

Масштаб: А - 100 мкм; B-D - 2 мкм; $\mathrm{E}-0,5$ мкм. 

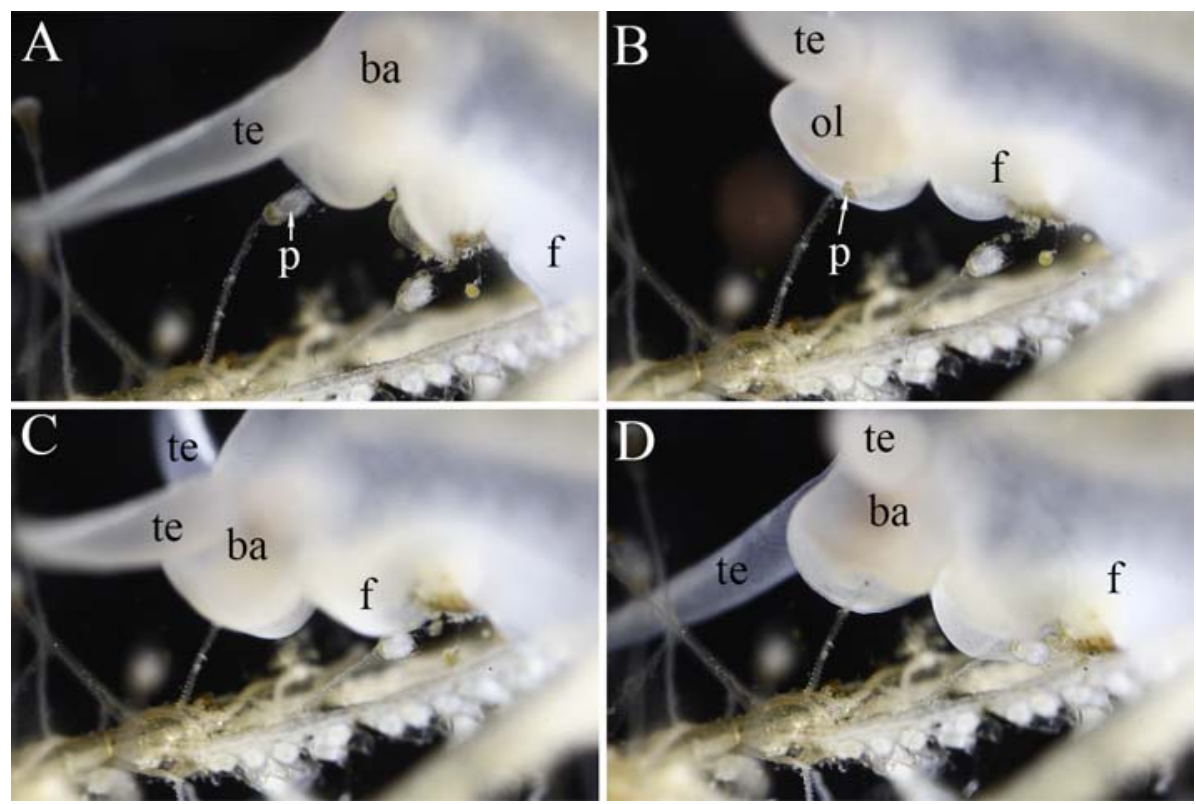

Fig. 12. Stages of feeding process, macrophotographs. A — food recognition (Time: $0 \mathrm{~s}$ ); B - food capture, mollusc sucks in the polyp(Time: $13 \mathrm{~s}$ ); C - trituration of the polyp within the buccal cavity (Time: $17 \mathrm{~s}$ ); $\mathrm{D}$ - end of the feeding process, the polyp is completely consumed (Time: $26 \mathrm{~s}$ ).

Abbreviations: ba - buccal apparatus; f - foot; ol — outer lip; $\mathrm{p}$ - polyp; rh — rhinophore; te — tentacle.

Рис. 12. Стадии процесса питания, макрофотографии. А - распознавание пищи (время: 0 c); В захват пищи, моллюск засасывает полипа (время: $13 \mathrm{c}$ ); С - измельчение полипа внутри буккальной полости (время: 17 c); D - окончание процесса питания, полип полностью потреблен (время: 26 с). Обозначения: ba - буккальный аппарат; f — нога; ol — внешняя губа; $\mathrm{p}$ — полип; rh — ринофор; te — щупальце.

1973; Crampton, 1977; Morse, 1984; Smith, 1988; García, García-Gómez, 1990). These muscles are absent in the buccal apparatus of $F$. verrucosa. By contrast, the buccal complex of $F$. verrucosa is attached to the body wall by groups of very thin fibres of connective tissue, which consist of single muscle cells and fibroblasts surrounded by extracellular matrix, according to data obtained with light microscopy and TEM. All muscles are located inside the buccal complex.

Another specific feature of $F$. verrucosa is an its intrinsic buccal musculature. This species has three groups of musculature: 1) the musculature linking the jaw plates to the wall of the buccal cavity, 2) the musculature originating from the posterior part of the jaw plates and inserting the odontophore, and 3) the odontophoral musculature, located in the ventral part of the odontophore under the radular bolster.
These groups of muscles are somewhat similar to those described in A. maculata (Nudibranchia: Euarminida) (García, García-Gómez, 1990) or in T. tetraquetra (Willows, 1978), but generally they represent another functional type of the buccal apparatus.

The most of the buccal musculature of the Patellogastropoda, Vetigastropoda and Caenogastropoda are muscles originating from the body wall or shell or branches of the other muscles (i.e. collumelar muscle) (Woodward, 1901; Fretter, Graham, 1962; Graham, 1973; Fretter, 1965; Nisbet, 1973; Guralnick, Smith, 1999). Many of them have similar functions to buccal muscles of $F$. verrucosa. Different groups of buccal muscles coordinate opening and closing of the mouth at the initial and final stages of food capture. They perform complex, "scratching" movements with the odontophore and these muscles also allow the mobility of the radular 

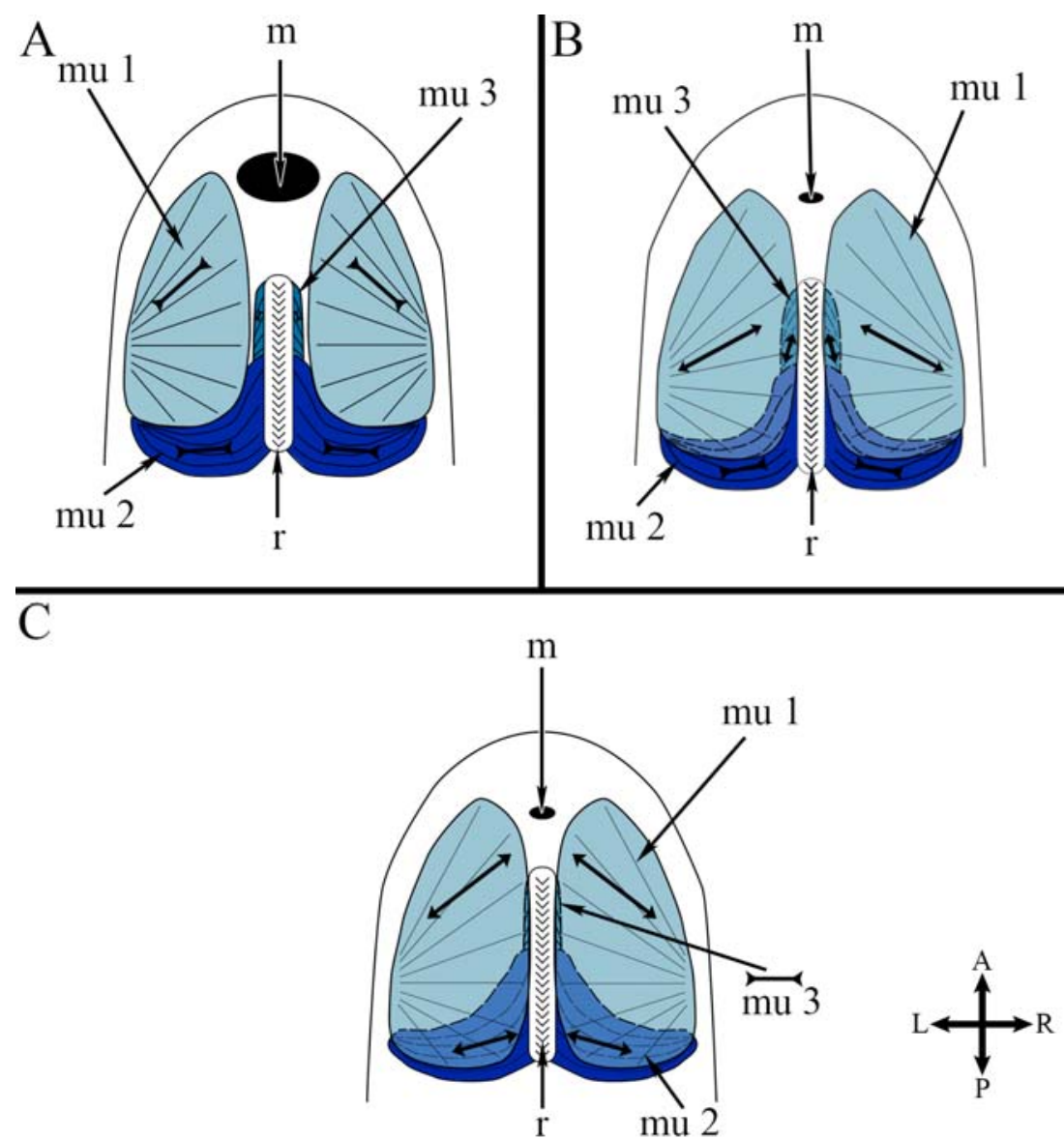

Fig. 13. Stages of the feeding process, diagram of the frontal view. A - first stage of the feeding process (according to discussion); B - second and third stages of the feeding process (according to discussion); $\mathrm{C}$ fourth stage of the feeding process (according to discussion). Outward and inward arrows indicate relaxed and contracted muscles correspondingly.

Abbreviations: $\mathrm{m}$ - mouth; mu 1 - jaw opener muscles; mu 2 - radular retractors; mu 3 - odontophoral protractor; $\mathrm{r}$ - radula.

Рис. 13. Схема основных стадий процесса питания, фронтальный вид. А - первая стадия процесса питания (см. Обсуждение); В - вторая и третья стадии процесса питания (см. Обсуждение); С четвертая стадия процесса питания (см. Обсуждение). Стрелки наружу и внутрь показывают расслабление и сокращение мышц соответственно.

Обозначения: $\mathrm{m}$ - рот; тu 1 - раскрыватели челюстей; тu 2 - радулярные ретракторы; тu 3 - протрактор одонтофора; r - радула.

ribbon (Herrick, 1906; Fretter, Graham, 1962; Graham, 1964, 1973; Fretter, 1965; Crampton, 1977; Willows, 1978; Kerth, 1983; Morse, 1984).

Based on the data of the general and fine morphology of the muscles, we suggest a scheme of operation of the buccal complex in F. verru$\cos a$. Multidirectional muscle bundles of the first group form a complex system of fibres, which opens the jaws, performing in a similar way with the jaw opener muscle in $T$. tetraquetra (Willows, 1978). Muscles of the second group are attached to the posterior part of jaw plate on the one side and to the upper side of the odontophore on the other, so we propose that they coordinate the actions of the jaws and 


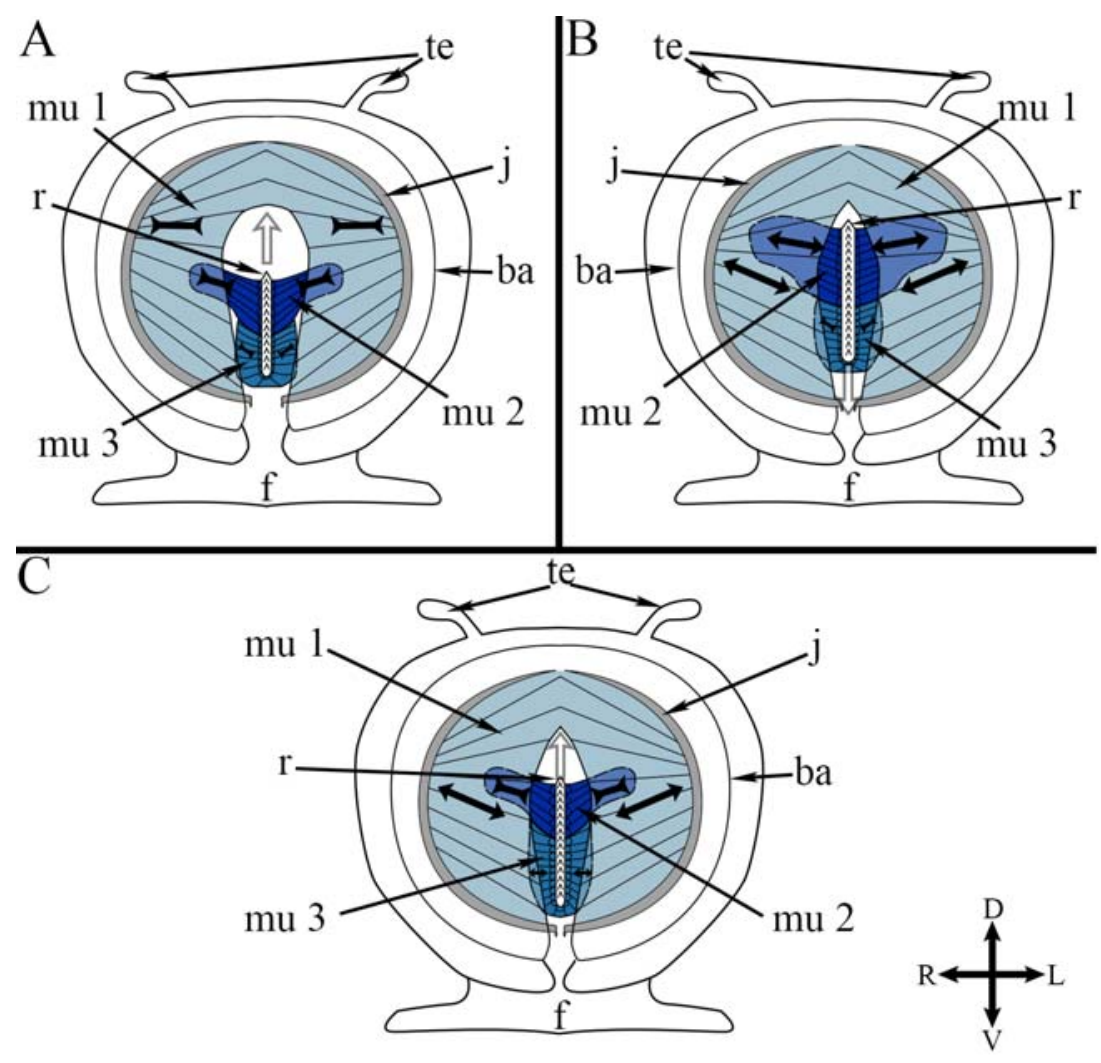

Fig. 14. Stages of the feeding process, diagram of the transverse view. A - first stage of the feeding process (according to discussion); $\mathrm{B}$ - second and third stages of the feeding process (according to discussion); $\mathrm{C}$ fourth stage of the feeding process (according to discussion). Outward and inward arrows indicate relaxed and contracted muscles correspondingly. White arrows show the radular and odontophoral movements. Abbreviations: ba - buccal apparatus; $\mathrm{f}$ - foot; $\mathrm{j}$ - jaw; mu 1 - jaw opener muscles; mu 2 - radular retractors; $\mathrm{mu}$ 3 - odontophoral protractor; $\mathrm{r}$ - radula; te - tentacles.

Рис. 14. Схема основных стадий процесса питания, поперечный вид. А - первая стадия процесса питания (см. Обсуждение); В - вторая и третья стадии процесса питания (см. Обсуждение); С четвертая стадия процесса питания (см. Обсуждение). Стрелки наружу и внутрь показывают расслабление и сокращение мышц соответственно. Белые стрелки показывают движения радулы и одонтофора.

Обозначения: ba - буккальный аппарат; $\mathrm{f}$ - нога; $\mathrm{j}$ - челюсть; mu 1 - раскрыватели челюстей; mu 2 радулярные ретракторы; тu 3 - протрактор одонтофора; $\mathrm{r}$ - радула; te - щупальца.

radular apparatus and at the same time work as a radular retractor. Finally, muscles of the third group move the odontophore itself. They fill the anterior and ventral parts of the odontophore and are attached at one end to the basal membrane of the subradular epithelium and at the other end to the muscles of the second group. Muscular fibres are directed postero-ventrally from the odontophoral tip. Light-microscopy images and TEM data show that they are obliquely striated. We suggest that these muscles work as an odontophoral protractor. Thus, functionally the muscles of buccal complex in $F$. verrucosa do not differ from buccal muscles in other gastropods, but the buccal muscles of $F$. verrucosa are attached to the jaw plates and not to the body wall as in other gastropods studied previously. 


\section{Function of the jaws}

The jaws of the Gastropoda are, in point of fact, the thickened cuticle of the buccal cavity. Sometimes it is organized in rodlets (Fretter, Graham, 1962; Ivanov, Starobogatov, 1990; Gosliner, 1994; Voltzow, 1994; Ponder, Lindberg, 1997; Barker, Efford, 2004; Vortsepneva et al., 2013, 2014). The jaws of $F$. verrucos $a$ are also a derivate of the cuticle. The buccal epithelium forms large folds which spread posterolaterally where the jaw plates are located. There are two main functions of jaws described formerly in Patello- and Vetigastropoda: 1) hermetic obstruction of the mouth while food processing to avoid the falling out of food particles to the environment and 2) protection of the buccal cavity from damaging effect of the radular movements (Woodward, 1901; Starmühlner, 1952; Hawkins et al., 1989). In the opisthobranchs jaws provide a surface for attachment of extrinsic and intrinsic buccal muscles and also take part in grasping and holding the prey (Willows, 1978; Morse, 1984). The jaws of $F$. verrucosa work as in other opisthobranchs, but, as stated above, there are not extrinsic muscles in its buccal apparatus. Therefore, there is one more function of jaws of $F$. verrucosa: they are only for support and work as an attachment place for the buccal muscles.

\section{Feeding mode}

According to published data on other representatives of Gastropoda, there are several main stages in the process of food acquisition and the functioning of the buccal complex: 1) opening of the mouth; 2) oral tube extrusion with first protraction of the buccal complex and odontophore and subsequent protrusion of the odontophore from the mouth; 3 ) extrusion and straightening of the radula over the odontophoral tip; 4) scratching movement of the odontophore along the substrate in a ventrodorsal direction; 5) retraction and folding of the radular ribbon; 6) retraction of the buccal complex, odontophore and oral tube and 7) closing of the mouth (Graham, 1973).
The external buccal musculature plays an important role in these stages. (Herrick, 1906; Carriker, 1946; Fretter, Graham, 1962; Graham, 1964, 1973; Fretter, 1965; Nisbet, 1973; Carriker et al., 1974; Crampton, 1977; Willows, 1978; Kerth, 1983; Morse, 1984; Smith, 1988; Ivanov, 1990). But in two species, O. bilamellata (Crampton, 1977) and P. californica (Morse, 1984), the buccal mass undergoes passive protrusion due to a large volume of haemolymph and increased pressure in the head haemocoel (Crampton, 1977; Morse, 1984). The absence of well-developed external buccal musculature in $F$. verrucosa suggests that the buccal mass in this species either does not protrude at all or protrudes passively in response to an increased haemolymph pressure. It also means that $F$. verrucosa cannot be a model object for typical generalist.

Jaw morphology has been studied for different Gastropoda species from different orders (Haszprunar, 1987; Ivanov, Starobogatov, 1990; Ponder, Lindberg, 1997; Barker, Efford, 2004; Vortsepneva et al., 2013, 2014). Several systematic groups, rank of suborders or lower, can be characterized by their specific jaw morphology. F. verrucosa is a member of the parvorder Aeolidida, so the morphology of their jaws is similar to other representatives of this group. Molluscs of the parvorder Aeolidida have paired jaws which cover the buccal complex. In the front part of each jaw plate there is a masticatory process (Marcus, Marcus, 1960; Willows, 1978; García, García-Gómez, 1990; Wägele, 1990, 1991; Gosliner, 1994; Kolb, 1998; Valdès et al., 2012).

$F$. verrucosa feeds on hydrozoans giving preference to the hydroids of the genera Obelia, Ectopleura and Eudendrium (Golikov, 1987; personal observation). According to the data on location and structure of muscles and also in vivo observation data, we present the following mechanism of function of the buccal apparatus.

1.F. verrucosa grasps or sucks in the whole polyp while feeding on a hydroid colony (Prudkovsky A., personal comment; Fig. 12A, B). It is possible due to the negative pressure in the buccal cavity which is created by the contrac- 
tion of all groups of buccal muscles (Figs 13A, 14A). Jaw opener muscles contract using jaw plates as a support, radular retractors and odontophoral protractor contract moving the odontophore back and down.

2. The elastic circular ligament of jaws works as antagonist of the jaw opener muscles. When these muscles relax, the contraction of the ligament makes the masticatory processes grip the stem of the hydrant (Fig. 12B).

3. Radular retractors relax, while odontophoral protractor remains contracted, that causes the working part of radula to expand and approach the polyp (Figs 13B, 14B).

4. Odontophoral protractor relaxes, radular retractors contract and the odontophore makes "rasping" movement, triturating the polyp and transferring the food pieces into the oesophagus (Figs 12C, 13C, 14C).

Then, third and fourth stages of feeding continue up to the complete consummation of the polyp (Fig. 12D).

The most similar to $F$. verrucosa feeding mechanism is a lunge-feeding mechanism, which was described in T. tetraquetra (Willows, 1978) and D. iris (Shaw, 1991). T. tetraquetra feeds on sea whips of the genus Virgularia; D. iris feeds on the tentacles of the ceriantharian Pachycerianthus fimbriatus McMurrich, 1910. Comparing feeding stages of these three nudibranch species we identified some differences in these processes. Firstly, recognition of food in $T$. tetraquetra and $D$. iris is provided by oral veil or oral tentacles, while in $F$. verrucosa food recognition is made by the outer lip (Video 1 ). Secondly, buccal complex in T. tetraquetra and $D$. iris protrudes during the feeding process, but the buccal complex of $F$. verrucosa does not protrude (Video 1). Thirdly, there is a bitestrike stage in the feeding process of $T$. tetraquetra and $D$. iris, which repeats several times. During this stage the masticatory processes of jaws cut the stem or tentacles of the mollusc's prey. In $F$. verrucosa the bite-strike stage is absent, because masticatory processes of the jaws are used not for cutting the stem of the polyp but for holding it. Furthermore, the morphology of radula of $F$. verrucosa differs from those of $T$. tetraquetra and $D$. iris significantly: the radulae of $T$. tetraquetra and $D$. iris are large and divided in two halves whereas the radula of $F$. verrucosa is small and united. Therefore, we suggest that the radula of $F$. verrucosa does not take part in biting the prey and is used only for trituration of (the) food.

Hereby, the feeding mechanism of $F$. verrucosa is a new type of feeding mode. Firstly, it is a generalist's feeding mode. Secondly, it combines suction and trituration of the food without any special morphological structures, such as buccal pump or specialized radular morphology.

\section{ACKNOWLEDGEMENTS}

We express our gratitude to the team of divers of N.A. Pertsov White Sea Biological Station and also to I.A. Ekimova (Department of Invertebrate Zoology, Biological faculty, Moscow State University) for providing material. We thank A. Prudkovsky for help with photographing and in vivo observations. We also thank Prof N. Biserova and I. Kosevich (Department of Invertebrate Zoology, Biological faculty, Moscow State University), G. Davidovich and A. Bogdanov (Laboratory of Electron Microscopy of Moscow State University), S. Metelev (I.D. Papanin Institute for Biology of Inland Waters, Russian Academy of Sciences), as well as Y. Smirnov (JSC Nanopromimport) for help with the electron microscopy studies.

This contribution was supported by the Russian Foundation for Basic Researches, grant No. 15-04-02580 (the collection of the material) and No. 14-50-0029 (transmission and scanning electron microscopy investigations). The electron microscopy investigations were performed at User Facilities Center of Lomonosov Moscow State University and at the Institute for Biology of Inland Waters of the Russian Academy of Sciences.

\section{References}

Andrews E.B. 1965. The functional anatomy of the gut of the prosobranch gastropod Pomacea canaliculata and of some other pilids // Proc. zool. Soc. Lond. Vol.145. No.1. P.19-36. 
Barker G.M., Efford M.G. 2004. Predatory gastropods as natural enemies of terrestrial gastropods and other invertebrates // Natural Enemies of Terrestrial Molluscs. UK, Wallingford: CABI Publishing. P.279403.

Bulloch A.G.M., Dorsett D.A. 1979. The functional morphology and the motor innervations of the buccal mass of Tritonia hombergi // J. Exp. Biol. Vol.79. P.7-22.

Carriker M.R. 1946. Observations on the functioning of the alimentary system of the snail Lymnaea stagnalis appressa Say // Biol. Bull. Vol.91. No.1. P.88-111.

Crampton D.M. 1977. Functional anatomy of the buccal apparatus of Onchidoris bilamellata (Mollusca: Opisthobranchia) // Trans. zool. Soc. Lond. Vol.34. No.1. P.45-86.

Eigenbrodt H. 1941. Untersuchungen über die Funktion der Radula einiger Schnecken // Zoomorphology. Bd.37. H.4. S.735-791.

Fretter V., Graham A. 1962. British Prosobranch Molluscs: Their Functional Anatomy and Ecology. UK, Dorking. 755 p.

Fretter V. 1965. Functional studies of the anatomy of some neritid prosobranchs // Proc. zool. Soc. Lond. Vol.147. No.1. P.46-74.

García F.J., García-Gómez J.C. 1990. The functional anatomy of the feeding apparatus of the nudibranch gastropod Armina maculata Rafinesque, 1814, with a comparison with some other opisthobranchs // J. Mollus. Stud. Vol.56. No.1. P.83-95.

Geddes. P. 1879. XIII. On the Mechanism of the Odontophore in certain Mollusca // Trans. zool. Soc. Lond. Vol.10. No.11. P.485-491.

Golikov A.N. 1987. [Class Gastropoda] // Starobogatov Y.I., Naumov A.D. (eds.). Molluski Belogo morya. Opredeliteli po faune SSSR, izd. Zool. Inst. AN SSSR. Leningrad: Nauka Publ. Vol.151. P.41-149 [in Russian].

Gosliner T.M. 1994. Gastropoda: Opisthobranchia // Harisson F.W., Kohn A.J. (eds.) Microscopic anatomy of invertebrates. New York: Wiley-Liss. Vol.5. P.253355.

Graham A. 1964. The functional anatomy of the buccal mass of the limpet (Patella vulgata) // Proc. zool. Lond. Vol.143. No.2. P.301-329.

Graham A. 1973. The anatomical basis of function in the buccal mass of prosobranch and amphineuran molluscs // J. Zool. Vol.169. No.3. P.317-348.

Guralnick R., Smith K. 1999. Historical and biomechanical analysis of integration and dissociation in molluscan feeding, with special emphasis on the true limpets (Patellogastropoda: Gastropoda) // J. Morphol. Vol.241. No.2. P.175-195.

Harasewych M.G., Petit R.E. 1986. Notes on the morphology of Admete viridula (Gastropoda: Cancellariidae) // Nautilus. Vol.100. No.3. P.85-91.

Haszprunar G. 1987. Anatomy and affinities of cocculinid limpets (Mollusca, Archaeogastropoda) // Zool. Scr. Vol.16. No.4. P.305-324.

Hawkins S.J. et al. 1989. A comparison of feeding mechanisms in microphagous, herbivorous, intertidal, proso- branchs in relation to resource partitioning // J. Mollusc. Stud. Vol.55. No.2. P.151-165.

Herrick J.C. 1906. Mechanism of the odontophoral apparatus in Sycotypus canaliculatus // Am. Nat. P.707737.

Hickman C.S., Morris T.E. 1985. Gastropod feeding tracks as a source of data in analysis of the functional morphology of radulae// Veliger. Vol.27. No.4. P.357365.

Hughes R.L. 1979. Ultrastructure of the buccal mass in juvenile Coryphella salmonacea (Gastropoda: Nudibranchia) // J. Mollusc. Stud. Vol.45. No.3. P.289295.

Huxley T.H. 1853. On the morphology of the cephalous Mollusca, as illustrated by the anatomy of certain Heteropoda and Pteropoda collected during the voyage of HMS "Rattlesnake" in 1846-50 // Phil. Trans. R. Soc. Lond. Vol.143. P.29-65.

Ivanov D.L. 1990. [The origin and early stages of evolutionary transformations of radular apparatus] // Rossolimo O.L. (ed.). Evolutsionnaya morphologiya molluskov (Zakonomernosti morfofunktsionalnykh perestroek radulyarnogo apparata). Moscow: MSU Publ. P.5-37 [in Russian].

Ivanov D.L., Starobogatov Y.I. 1990. [Revisited origin and evolution of mandibular formations in phylum Mollusca] // Rossolimo O.L. (ed.). Evolutsionnaya morphologiya molluskov (Zakonomernosti morfofunktsionalnykh perestroek radulyarnogo apparata). Moscow: MSU Publ. P.198-205 [in Russian].

Kantor Y.I. 1990. Anatomical basis for the origin and evolution of the toxoglossan mode of feeding // Malacologia. Vol.32. No.1. P.3-18.

Kantor Yu.I., Harasewych M.G. 1992. Morphology of the digestive system of Volutomitra alaskana Dall, 1902 (Gastropoda, Pectinibranchia, Volutomitridae), with notes on the possible mechanism of feeding // Ruthenica. Vol.2. No.1. P.45-53.

Katsuno S., Sasaki T. 2008. Comparative histology of radula-supporting structures in Gastropoda // Malacologia. Vol.50. No.1. P.13-56.

Kerth K. 1983. Radulaapparat und Radulabildung der Mollusken. I. Vergleichende Morphologie und Ultrastruktur // Zool. Jahrb. Anat. Bd.110. S.205-237.

Kolb A. 1998. Morphology, anatomy and histology of four species of Armina Rafinesque, 1814 (Nudibranchia, Arminoidea, Arminidae) from the Mediterranean Sea and the Atlantic Ocean // J. Mollusc. Stud. Vol. 64. No.3. P.355-386.

Luchtel D.L. et al. 1997. Gastropoda: Pulmonata // Harisson F.W., Kohn A.J. (eds.). Microscopic anatomy of invertebrates. New York: Wiley-Liss. Vol.6B. P.459718.

Marcus E., Marcus E. 1960. Opisthobranchs from American Atlantic warm waters // Bull. Mar. Sci. Gulf. Caribb. Vol.10. No.2. P.129-203.

Millonig G. 1964. Study on the factors which influence preservation of fine structure // Symposium on electron microscopy. Rome: Consiglio Nazionale delle Ricerche. P.347. 
Morris T.E., Hickman C.S. 1981. A method for artificially protruding gastropod radulae and a new model of radula function // Veliger. Vol.24. P.85-89.

Morse M.P. 1984. Functional adaptations of the digestive system of the carnivorous mollusc Pleurobranchaea californica MacFarland, 1966 // J. Morphol. Vol.180. No.3. P.253-269.

Nisbet R.H. 1973. The role of the buccal mass in the trochid // J. Mollusc. Stud. Vol.40. No.6. P.435-468.

Padilla D.K. 2004. Form and function of radular teeth of herbivorous molluscs: focus on the future // Am. Malacol. Bull. Vol.18. No.1/2. P.163-168.

Ponder W.F., Lindberg D.R. 1997. Towards a phylogeny of gastropod molluscs: an analysis using morphological characters // Zool. J. Linn. Soc. Vol.119. No.2. P.83-265.

Shaw G.D. 1991.Chemotaxis and lunge-feeding behaviour of Dendronotus iris (Mollusca: Opisthobranchia) // Can. J. Zool. Vol.69. P.2805-2810.

Smith D.A. 1988. Radular kinetics during grazing in Helisoma trivolvis (Gastropoda: Pulmonata) // J. Exp. Biol. Vol.136. No.1. P.89-102.

Starmühlner F. 1952. Zur Anatomie, Histologie und Biologie einheimischer Prosobranchier // Österr. Zool. Zeitschr. Bd.3. H.5. S.546-590.

Valdès Á., Moran A.L., Woods H.A. 2012. Revision of several poorly known Antarctic aeolid nudibranch species (Mollusca: Gastropoda), with the description of a new species // J. Mar. Biol. Assoc. UK. Vol.92. No.5. P.1161-1174.

Voltzow J. 1994. Gastropoda: Prosobranchia // Harisson F.W., Kohn A.J. (eds.). Microscopic anatomy of in- vertebrates. New York: Wiley-Liss. Vol.5. P.111252.

Vortsepneva E., Ivanov D., Purschke G., Tzetlin A. 2013. Morphology of the jaw apparatus in 8 species of Patellogastropoda (Mollusca, Gastropoda) with special reference to Testudinalia tesulata (Lottiidae) // Zoomorphology. Vol.132. No.4. P.359-377.

Vortsepneva E., Ivanov D., Purschke G., Tzetlin A. 2014. Fine morphology of the jaw apparatus of Puncturella noachina (Fissurellidae, Vetigastropoda) // J. Morphol. Vol.275. No.7. P.775-787.

Wägele H. 1990. Revision of the Antarctic genus Notaeolidia (Gastropoda, Nudibranchia), with a description of a new species // Zool. Scr. Vol.19. No.3. P.309330 .

Wägele H. 1991. Studies on the morphology and anatomy of the Antarctic nudibranch genera Pseudotritonia Thiele, 1912 and Telarma Odhner, 1934 with a discussion of the family Charcotiidae Odhner, 1926 (Nudibranchia: Opisthobranchia) // Zool. J. Linn. Soc. Vol.101. No.4. P.359-389.

Willows A.O.D. 1978. Physiology of feeding in Tritonia I. Behavior and mechanics // Mar. Behav. Physiol. Vol.5. No.2. P.115-135.

Woodward M.F. 1901. The Anatomy of Pleurotomaria Beyrichii // Quart. J. Micr. Sci. Vol.44. P.215-268.

Responsible editor E.N. Temereva

EXTENSION (available at site)

Video 1. Feeding process of Flabellina verrucosa. Видео 1. Процесс питания Flabellina verrucosa. 